\title{
Dynamics of exopolymeric carbon pools in relation with phytoplankton succession along the salinity gradient of a temperate estuary (France)
}

\author{
Morelle Jérôme ${ }^{1,2}$, Schapira Mathilde ${ }^{3}$, Francoise Sylvaine ${ }^{3}$, Courtay Gaëlle ${ }^{3}$, Orvain Francis ${ }^{1,2}$, \\ Claquin Pascal ${ }^{1,2, *}$
}

${ }^{1}$ Normandie Universités, Université de Caen Normandie, F-14032, Caen, France

${ }^{2}$ Unité Biologie des ORganismes et Ecosystèmes Aquatiques (BOREA, UMR 7208), Sorbonne Universités, Muséum National d'Histoire Naturelle, CNRS, Université Pierre et Marie Curie, Université de Caen Normandie, IRD 207, Université des Antilles, Esplanade de la paix, F-14032, Caen, France

${ }^{3}$ Ifremer, LER/N, Avenue du Général de Gaulle, 14520, Port-en-Bessin, France

* Corresponding author : Pascal Claquin, email address : pascal.claquin@unicaen.fr

\begin{abstract}
:
In parallel to phytoplankton community dynamics, transparent exopolymeric particles (TEP) and exopolymeric substances (EPS) were investigated along the salinity gradient of a temperate estuary (Seine estuary, Normandy, France) over the course of a year. The phytoplankton community was mainly dominated by marine diatom species (especially Skeletonema sp., Nitzschia sp., and Paralia sulcata) associated with a spring bloom of pico-eukaryotes and the development of Cryptophyceae in summer. The decreases in species richness and salinity were correlated along the estuary and a significant exponential relationship between species richness and primary production was identified. Concentrations of TEP and EPS (soluble and bound carbohydrates) are highly dynamic in this estuary and can reach respectively $69 \mathrm{mgC} \mathrm{L}^{-1}$, and $33 \mathrm{mgC} \mathrm{L}^{-1}$. TEP distribution was mainly related to physical factors (hydrodynamics, maximum turbidity zone formation and sediment resuspension) probably produced by stressed or dying phytoplankton, while EPS appeared to be excreted during the phytoplankton spring bloom. Soluble and bound EPS appear to be related to Skeletonema sp. and Cryptophyceae occurrences. This paper presents the dynamic pattern of these carbon pools, which play an important role in the trophic network and influence the flocculation processes involved in the fate of both organic and inorganic matter.
\end{abstract}




\section{Graphical abstract}

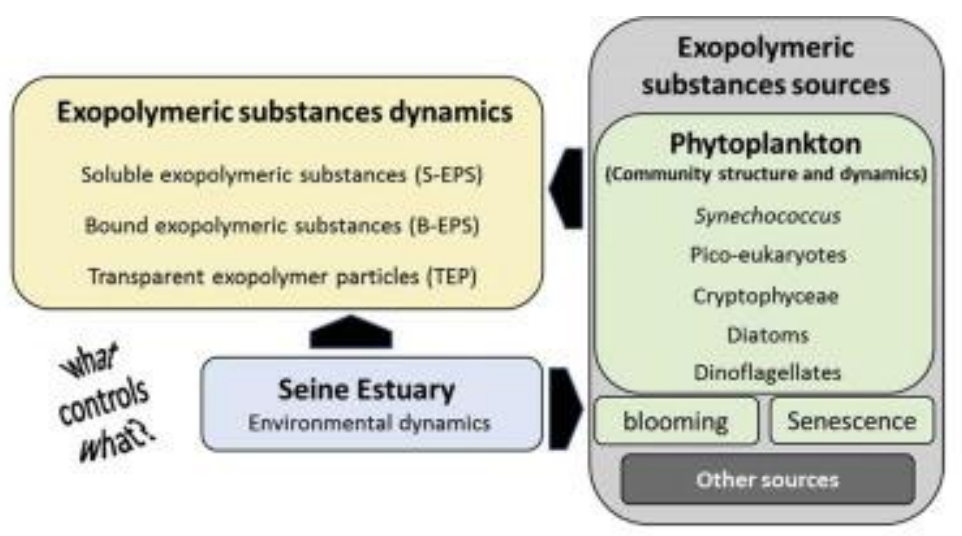

Keywords : Picophytoplankton, Nanophytoplankton, Exopolymeric substances, Species richness 


\section{Introduction}

Estuaries are transitional zones between two aquatic biomes: a freshwater biome in a river

39 and a marine biome along a coast or in a bay. Transitional zones between two biomes are often

40 characterized by pronounced changes in community composition and diversity, and, as such, can be

41 defined as ecotones or ecoclines (Van Der Maarel 1990). An ecotone is defined as a dynamic zone

42 where rapid environmental changes occur and is characterized by unique communities that differ

43 from the communities inhabiting the two adjacent biomes. In contrast, an ecocline is defined as a

44 zone with gradual changes in environmental conditions and where a continuum of assemblages is

45 observed along the gradients. While estuaries have traditionally been defined as ecotones, since the

46 beginning of the $21^{\text {st }}$ century several studies have defined them as ecoclines (Attrill and Rundle

47 2002; Cortelezzi et al. 2007; Muylaert et al. 2009). The strong gradients occurring in estuaries

48 (mainly in salinity, turbidity and nutrients) are selective forces of species and drive temporal and

49 spatial successions of phytoplankton. These factors are known to influence both phytoplankton

50 biomass and community structure (Trigueros and Orive 2000; Lionard et al. 2008; Muylaert et al. 
2009; Vigil et al. 2009). These types of changes could have a strong impact on the marine system and on the stoichiometry, carbon storage and biogeochemistry (Marinov et al. 2010).

The carbon pool in estuaries mainly originates from phytoplanktonic and microphytobenthic primary production (Cloern et al. 2014) and is available in the form of cellular biomass and exopolymeric substances (EPS). Excretion of EPS by phytoplankton (Decho 1990; Alldredge et al. 1993; Passow and Alldredge 1994) creates a great carbon reserve and is an important component of the carbon budget. These fibrillary polymers may coagulate to form larger particles, called transparent exopolymeric substances (TEP). The abiotic formation of TEP from colloidal precursors depends on environmental conditions such as turbulence, ion density, and the concentration of inorganic colloids, as well as on the types and concentrations of the precursors present (Passow 2002). Some of these substances are degraded by microbial and bacterial respiration, resulting in the release of carbon in the form of $\mathrm{CO}_{2}$ (Passow 2002). The other part migrates to deep layers as aggregates and, if not re-suspended, is involved in carbon sequestration (Legendre and Rivkin 2002). EPS thus play a major role in aggregation processes, particle sedimentation and carbon fluxes in particulate organic matter in aggregates on particles or dissolved in water. EPS and TEP dynamics are also greatly controlled by the microbial loop which influences enzymatic break down and the conversion of EPS into dissolved organic matter (Bhaskar and Bhosle 2005). The microbial loop

71 forms an important alternative way for organic carbon cycle in the aquatic ecosystems. Moreover,

72 EPS are used as an important source of carbon and energy by numerous organisms in aquatic trophic network (Bhaskar and Bhosle 2005). In estuarine systems, EPS have been shown to account for a large proportion of the colloidal organic carbon pool in the water column (Annane et al. 2015) and 
where suspended particle matter (SPM) accumulates (Malpezzi et al. 2013; Morelle et al. 2017).

However, although estuaries may present very high concentration of TEP, it is regularly reported that

no direct correlation can be found with the phytoplankton dynamics such as the concentration of chlorophyll $a(\operatorname{chl} a)$ or primary productivity (Garcia 2002; Corzo et al. 2005; Klein et al. 2011; Chowdhury et al. 2016).

As in addition to primary production, estuaries are important ecosystems in terms of carbon sequestration and export (Cai 2011), a greater knowledge of EPS dynamics is an absolute prerequisite for a better understanding of carbon fluxes in these transitional zones. However, most research on EPS in estuaries to date has focused on their production by microphytobenthic communities and only a few authors have studied EPS and TEP dynamics in the estuarine water column (Wetz et al. 2009; Annane et al. 2015; Morelle et al. 2017). As the different phytoplankton groups and species do not have the same rates of polysaccharide production, chla concentration, sinking rate or photosynthetic efficiency, spatial and temporal variations in phytoplankton size and community structure could explain the previously described absence of correlation between EPS and phytoplankton dynamics (Garcia 2002; Corzo et al. 2005; Klein et al. 2011; Chowdhury et al. 2016). It is thus important to consider the influence of the succession of different phytoplankton communities in relation with the TEP and EPS distribution in estuaries.

In this context, the aim of this study was to investigate the seasonal dynamics of exopolysaccharides (EPS and TEP), phytoplankton community structure and size class distribution in a temperate estuary (Seine, Normandy, France) in order to study, in addition to physical and chemical variability, how spatial and temporal changes in phytoplankton communities could trigger EPS and TEP dynamics along the salinity gradient.

\section{Methods}

\subsection{Study site}


The Seine River and its estuary drains a watershed covering $76,260 \mathrm{~km}^{2}$. After Paris, the river flows northwest and drains into the English Channel (Fig. 1). Located $202 \mathrm{~km}$ from Paris (the

kilometric scale of the Seine River is set at $0 \mathrm{~km}$ in the center of Paris), the weir at Poses (Fig. 1)

represents the upper limit of the tidal propagation in the Seine estuary. The annual average river

discharge at Poses is $436 \mathrm{~m}^{3} \cdot \mathrm{s}^{-1}$ with a flood period extending from December to April when the

discharge reaches $1200-2500 \mathrm{~m}^{3} \cdot \mathrm{s}^{-1}$ and a low-flow period with a discharge around $250 \mathrm{~m}^{3} \cdot \mathrm{s}^{-1}$ (Data GIP Seine-Aval, 2008; 2011). In the oligohaline part, salinity ranges from 0.5 to 5 ; in the mesohaline part salinity ranges from 5 to 18 ; in the polyhaline part from 18 to 30 ; and in the euhaline part, salinity is above 30 . The Seine estuary is a macrotidal estuary, with a tidal amplitude ranging from 3-

$7 \mathrm{~m}$ at Honfleur and 1-2 $\mathrm{m}$ at Poses (Fig. 1). The mean residence time in the estuary varies between

17-18 days for a discharge of $200 \mathrm{~m}^{3} \mathrm{~s}^{-1}$ at Poses and between 5-7 days for a discharge of $1000 \mathrm{~m}^{3} \mathrm{~s}^{-1}$

(Brenon and Hir 1999; Even et al. 2007). The tide in the Seine estuary is characterized by flattening

at high tide lasting more than 2 hours due to the deformation of the tidal wave during the propagation at shallow depths (Brenon and Hir 1999; Wang et al. 2002). The flow is asymmetric in favor of the flood and this trend increases as the tide propagates up the estuary. Seasonally, water temperature ranges between $25{ }^{\circ} \mathrm{C}$ in summer and $7{ }^{\circ} \mathrm{C}$ in winter with differences of less than $1{ }^{\circ} \mathrm{C}$ along the longitudinal profile and a weak vertical gradient (Data GIP Seine-Aval, 2008; 2011). The turbidity maximum zone (MTZ), containing up to $2 \mathrm{~g} \mathrm{~L}^{-1}$ of SPM, is most often located between Honfleur and

Tancarville, but can move upstream depending on the intensity of the tide and on river discharge.

During winter flood events, the MTZ can be flushed out into the Seine Bay (Etcheber et al. 2007;

Garnier et al. 2010).

\subsection{Sampling strategy}

Sampling was conducted monthly from January to December 2015 onboard the Ifremer ship 
zone (site 1) to the oligohaline zone (site 8). In order to sample a steady waterbody along the estuary, sampling was performed every month in spring tide conditions (tidal coefficient 90) during daylight and during flattening of the high tide, which, in these conditions, lasts up to three hours. At each sampling site, water was sampled with a pump from the sub-surface (i.e. at a depth of $1 \mathrm{~m}$ ) and with

a Niskin bottle at the water-sediment interface (WSI) (i.e. $1 \mathrm{~m}$ above) for analysis of the physicalchemical (SPM, nutrients) and biological parameters (chl $a$, exopolysaccharides and community structure). Vertical salinity profiles (measured using the practical salinity unit; PSU), turbidity (measured using the nephelometric turbidity unit; NTU) and temperature $\left({ }^{\circ} \mathrm{C}\right)$ were recorded at each site with a SBE 19-plusVD CTD (Seabird) from the sub-surface down to $1 \mathrm{~m}$ above the watersediment interface (WSI). In these conditions, the mean sampling depth at the WSI is $13.2 \pm 1.4$ et al. 2018) and a slight summary of their dynamics is given in this paper.

\subsection{Phytoplankton biomass}

determine the total chla concentration and through polycarbonate filters (Millipore, $10 \mu \mathrm{m}$ ) to

determine the phytoplankton biomass of the $>10 \mu \mathrm{m}$ size fraction. The phytoplankton biomass of the $<10 \mu \mathrm{m}$ size fraction was calculated as the difference between the total and $>10 \mu \mathrm{m} \operatorname{chl} a$ concentrations. Filters were immediately frozen $\left(-20^{\circ} \mathrm{C}\right)$ until analysis. In the laboratory, pigments were extracted in $10 \mathrm{~mL}$ of $90 \%(\mathrm{v} / \mathrm{v})$ acetone at $4{ }^{\circ} \mathrm{C}$ for $12 \mathrm{~h}$ in the dark. After centrifugation at $2000 \mathrm{~g}$ at $4{ }^{\circ} \mathrm{C}$ for 10 minutes the concentration of chla with acidification $(\mathrm{HCl} 0.1 \mathrm{M})$ was measured on extracts following the fluorometric method of Lorenzen (1966) using a Turner Trilogy 


\subsection{Phytoplankton identification and enumeration}

\subsubsection{Micro-phytoplankton}

At sites 1, 3, 5, and 7: $250 \mathrm{ml}$ of sub-surface water were sampled, preserved in Lugol iodine solution (2\% f.c.) and stored at $4{ }^{\circ} \mathrm{C}$ in the dark until identification and enumeration of microphytoplankton species according to the Utermöhl method (Lund et al. 1958). Briefly, $10 \mathrm{ml}$ of sample were left to settle in counting cells for 24 hours. Identification and quantification were then carried out under an inverted microscope with contrast phase optics. Identification was done to the lowest possible taxonomic level. Due to the high turbidity and suspended particles matter in the samples, the specific abundance of cells in an accurate and exhaustive way has proved to be impossible and, therefore, the enumeration of micro-phytoplankton was given only in terms of presence / absence with an estimation of the total abundance of diatoms and dinoflagellates cells.

\subsubsection{Pico- and nano-phytoplankton}

Water samples $(1 \mathrm{ml})$ were collected in triplicate, fixed with $0.25 \%$ (f.c.) of glutaraldehyde, maintained at $4{ }^{\circ} \mathrm{C}$ for 15 minutes in the dark before being deep-frozen in liquid nitrogen (Vaulot $e t$ al. 1989; Olson et al. 1993). Back in the laboratory, samples were stored at $-80{ }^{\circ} \mathrm{C}$ for less than 6 months before analysis by flow cytometry (FCM). Analyses were carried out on a Gallios flow cytometer (Beckman Coulter®) at the FCM facilities of the structure fédérative ICORE 146. After being quick thawed and without pre-treatment, pico- and nano-phytoplankton cells were distinguished and enumerated by FCM according to their specific auto-fluorescence and light scatter properties (Marie et al. 1999; Pan et al. 2005). The forward-angle light scatter (FSC), right-angle light scatter (SSC), and both red (FL4; $\lambda=695 \mathrm{~nm}$ ) and orange (FL3; $\lambda=620 \mathrm{~nm}$ ) fluorescence of each sample were recorded. Fluorescent beads (diameter $1 \mu \mathrm{m})$ (Molecular Probes, Eugene, Oregon) were added as internal standard to all samples. The concentrations of beads were estimated after each 
176 FCM session under epifluorescence microscopy to ensure reliability of this concentration, and all

177 FCM parameters were normalized to it and to fluorescence. Synechococcus sp., autotrophic pico-

178 eukaryotic cells and Cryptophyceae were distinguished by side-angle light scatter (SSC) versus 179 orange fluorescence (from phycoerythrin) and red fluorescence (from chlorophyll), according to 180 standard protocols (Marie et al. 1999; Pan et al. 2005). The pico- and nano-phytoplankton was 181 identified and abundance was measured at the different sites from January to September 2015. Due 182 to conservation problems, samples collected from October to December could not be rigorously 183 exploited. The different subpopulations were distinguished based on their fluorescence and size and 184 all cytometric sub-population of each genus have been statistically tested. To our knowledge, these are the first observations of pico- and nano-phytoplankton cells in the Seine estuary.

\subsection{Exopolysaccharide analysis}

\subsubsection{Exopolysaccharides (EPS)}

Carbohydrate contents were measured following Dubois's method (Dubois et al. 1956;

Orvain et al. 2014), with glucose as the standard. Briefly, 10 to $50 \mathrm{ml}$ of each sample were filtered onto Whatman GF/F glass fiber filters. The filtrates were considered as colloidal EPS (S-EPS) and stored at $-20{ }^{\circ} \mathrm{C}$. In addition to S-EPS, bound EPS (B-EPS) were extracted from the filters. For that purpose, the filters were placed in $15 \mathrm{ml}$ centrifugation tubes with $12 \mathrm{ml}$ of $0.2 \mu \mathrm{m}$ filtered and sterilized artificial sea water (ASW) and $\sim 1 \mathrm{~g}$ of activated cationic resin (Dowex Marathon $\mathrm{C}, \mathrm{Na}^{+}$; Sigma-Aldrich). The tubes were agitated gently for 1 hour at $4{ }^{\circ} \mathrm{C}$ in the dark and then centrifuged at $3000 \mathrm{~g}$ at $4{ }^{\circ} \mathrm{C}$ for $10 \mathrm{~min}$. The supernatants were collected and stored at $-20{ }^{\circ} \mathrm{C}$ for further analysis of B-EPS. After the supernatants were thawed at room temperature, high and low molecular weight EPS was extracted by incubating $3 \mathrm{ml}$ of each sample in $7 \mathrm{ml}$ ethanol (70 \% f.c.) at $-20{ }^{\circ} \mathrm{C}$ for 16 hours. The samples were centrifuged at $3000 \mathrm{~g}$ at $4{ }^{\circ} \mathrm{C}$ for $30 \mathrm{~min}$ and the supernatants containing low molecular weight EPS were discarded. The pellet containing high molecular weight EPS was 
dried at $50{ }^{\circ} \mathrm{C}$ overnight. The dried samples were re-suspended in $3 \mathrm{ml}$ distilled water. To estimate carbohydrate contents, $50 \mu \mathrm{L}$ of $5 \%$ phenol and $250 \mu \mathrm{L}$ sulfuric acid were added to $50 \mu \mathrm{L}$ of the extract, and vortexed. After 30 min, absorption was read with a FlexStation plate reader (Molecular Devices) at $485 \mathrm{~nm}$, using glucose as standard for the calibration curve. EPS concentrations were estimated for each site and are expressed in $\mu \mathrm{gGeq} \cdot \mathrm{L}^{-1}$. These concentrations were then converted into carbon using a coefficient of 0.4 corresponding to the carbon mass coefficient in one molecule of glucose.

\subsubsection{Transparent exopolymeric particles (TEP)}

The concentration of TEP was determined using the colorimetric method described by Claquin et al. (2008) and adapted from Passow and Alldredge (1995). Briefly, 15 to $50 \mathrm{ml}$ samples were filtered onto $0.4 \mu \mathrm{m}$ polycarbonate Isopore membrane filters (Millipore) and stored at $-20{ }^{\circ} \mathrm{C}$ until analysis. Particles retained on the filters were stained with $5 \mathrm{ml}$ of $0.02 \%$ Alcian blue (Sigma) in $0.06 \%$ acetic acid $(\mathrm{pH} 2.5)$. After centrifugation at $3500 \mathrm{~g}$ for $30 \mathrm{~min}$, the supernatant was removed and the filter was rinsed with $5 \mathrm{ml}$ of MilliQ water and centrifuged several times until all excess dye was completely removed from the pellet. After one night of drying in a sterilizer at $50{ }^{\circ} \mathrm{C}$, $6 \mathrm{ml}$ of $80 \% \mathrm{H}_{2} \mathrm{SO}_{4}$ were added and 2 hours later the absorbance of the supernatant was measured at $787 \mathrm{~nm}$ using a spectrometer. Alcian blue absorbance was calibrated using a solution of Xanthan Gum (XG). TEP concentrations are expressed in $\mu \mathrm{gXGeq} / \mathrm{L}$. The concentrations were then converted into carbon using a coefficient of 0.7 (Engel and Passow 2001; Claquin et al. 2008).

\subsection{Data analysis}

The plots were performed for each parameter studied by taking the spatial and temporal dynamics into account using SigmaPlot software (v.12.5). Correlations between EPS and the other parameters studied were tested by calculating Spearman's correlation coefficient using SigmaPlot 
software (v.12.5). A principal component analysis (PCA) was performed using the "FactoMineR" package in $\mathrm{R}$ on data collected from the sub-surface and close to the WSI at all sampling sites in all the studied period.

\section{Results}

\section{Hydrological parameters}

The Seine River flow decreased progressively from January to July 2015 with the maximum values reaching $1240 \mathrm{~m}^{3} \mathrm{~s}^{-1}$ in February and May. Between July and November, the flow was around $500 \mathrm{~m}^{3} \mathrm{~s}^{-1}$, and the minimum value $\left(155 \mathrm{~m}^{3} \mathrm{~s}^{-1}\right)$ was observed at the beginning of August. An increase in flow was recorded at the end of November. The irradiance level was affected by a typical seasonal trend, with the highest value $\left(1.13 \times 10^{8} \mu \mathrm{mol}\right.$ photons $\left.\mathrm{m}^{-2} \mathrm{~d}^{-1}\right)$ observed in June. Water temperature also followed a typical seasonal pattern over the course of the year with the highest value $\left(21.9^{\circ} \mathrm{C}\right)$ measured in sub-surface water during July and the lowest $\left(5.1^{\circ} \mathrm{C}\right)$ measured close to the WSI during February in the oligohaline zone. An inversion of the temperature gradient was observed over the course of the year in sub-surface, with temperature increasing from downstream to upstream in winter, and inversely in summer. Salinity showed a dilution gradient in sub-surface from downstream to upstream. While a similar gradient was observed close to the WSI, it was more disparate and patches of fresh or salty water were observed. The highest salinity value (29.9) was measured close to the WSI at site 2 in November. The highest concentrations of SPM were measured in winter in both sub-surface and bottom waters. In sub-surface waters, the concentrations were often homogeneous along the salinity gradient. Some patches of higher concentration were observed close to the WSI out of the MTZ. The MTZ was located at site 8 from January to February, and at site 5 248 from November to December, with values higher than $0.1 \mathrm{~g} \mathrm{~L}^{-1}$ in sub-surface. Close to the WSI, 249 SPM concentrations were higher $\left(>0.2 \mathrm{~g} \mathrm{~L}^{-1}\right)$ especially in the MTZ, with a maxima of $2.7 \mathrm{~g} \mathrm{~L}^{-1}$ 250 observed in December at site 8. A correlation was found between SPM concentrations and turbidity 
251 (Person correlation coefficient: 0.58, $\mathrm{p}<0.001, \mathrm{n}=148$ ) throughout the salinity gradient and over the

entire studied period. Turbidity presented a clear gradient in the sub-surface water with an increase in turbidity values from downstream to upstream and confirmed the position of the MTZ defined with SPM concentrations.

The concentrations of DIN and silicates were higher in sub-surface waters than in close to the WSI throughout the salinity gradient and over the entire studied period. The highest values (up to

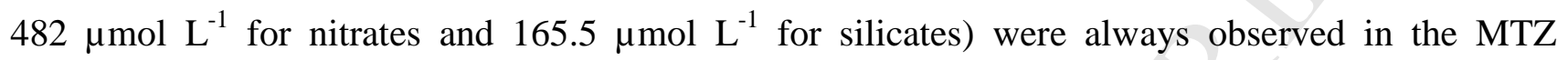
especially during the flood period. The lowest concentration of DIN $\left(40.9 \mu \mathrm{mol} \mathrm{L}^{-1}\right)$ was measured close to the WSI in August and the lowest concentrations of silicates $\left(17 \mu \mathrm{mol} \mathrm{L}^{-1}\right)$ in May, both at site 2. In sub-surface waters, a clear pattern of dilution was observed for DIN concentrations with a decrease in [DIN] values from upstream to downstream. Close to the WSI, the concentrations of DIN were more disparate along the salinity gradient, despite a dilution being observed from upstream to downstream. The dilution pattern of the silicates was similar to the DIN pattern at both depth (Person correlation coefficient: $0.88, \mathrm{p}<0.001, \mathrm{n}=148$ ). Phosphate concentrations followed a different pattern characterized by weak differences between sub-surface and bottom waters throughout the salinity gradient. The highest values $\left(>4 \mu \mathrm{mol} \mathrm{L}^{-1}\right)$ were observed upstream close to the WSI at sites $7 \& 8$ in August, and the lowest value $\left(0.6 \mu \mathrm{mol} \mathrm{L} \mathrm{L}^{-1}\right)$ was measured close to the WSI at site 2 in May. In March, a patch of freshwater was observed close to the WSI at site 3 (longitude 0.27), characterized by low salinity, high turbidity and high concentrations of nutrients.

\subsection{Dynamics of the size fractionated phytoplankton biomass}

The total chla concentrations in the sub-surface layer ranged from 0.2 to $15.9 \mu \mathrm{g} \mathrm{L}^{-1}$. A decreasing trend was observed from downstream to upstream from April to October (Fig. 2). Close to the WSI, values ranged between 0.4 to $21.8 \mu \mathrm{g} \mathrm{L}^{-1}$ and despite the surprisingly high values 
recorded in winter (>10 $\left.\mu \mathrm{g} . \mathrm{L}^{-1}\right)$ in the oligohaline zone, the same gradient was observed as in the sub-surface layer (Fig. 3).

High concentrations of small cells $(<10 \mu \mathrm{m})$ were recorded from June to September in the

downstream part, the highest value $\left(9.6 \mu \mathrm{g} \mathrm{L}^{-1}\right)$ being recorded at site 2 in July. Close to the WSI, 279 high concentrations were recorded from May to September with the highest value $\left(5.05 \mu \mathrm{g} \mathrm{L}^{-1}\right)$ recorded at site 4 in June. In winter, the highest value $\left(6.9 \mu \mathrm{g} \mathrm{L}^{-1}\right)$ was recorded in the oligohaline zone (site 8) in December.

High concentrations of large cells $(>10 \mu \mathrm{m})$ were recorded from April to October, the zone (site 8) in October. detrital matter than living phytoplankton (Morelle et al. 2018).

\subsection{Micro-phytoplankton assemblages}

Over the course of the year, 39 distinct taxonomic units of diatoms were observed, 13 distinct taxonomic units of dinoflagellates, and six other taxonomic units of algae, representing a species richness of 58 taxonomic units identified in the Seine estuary. Most were identified at the downstream sites $(1 \& 3)$ in spring and summer (Table 1). The high turbidity and the high SPM concentrations in the samples prevented more precise exploitation of this method. The mean species richness per site was 5.56 for diatoms, 1.58 for dinoflagellates, 0.44 for eukaryotes and 7.58 for all taxonomic units taken together. The most frequent diatoms in the 48 samples were Nitzschia sp., observed in 32 samples; Skeletonema sp., observed in 25 samples; Paralia sulcata, observed in 23 samples; and Rhizosolenia sp., observed in 22 samples. The most frequent dinoflagellates were 
300 Scripsiella sp., observed in 14 samples and Prorocentrum sp., observed in 11 samples (Table 1).

301 Despite being the most frequently observed over the course of the year, the four diatoms species 302 cited earlier were also predominant in some samples (not enumerated) with in winter a majority of 303 Paralia sulcata and Asterionelopsis glacialis; in spring and summer, a majority of Skeletonema sp., 304 Nitzschia sp., and Chaetoceros sp., and in October, a majority of Rhizosolenia imbricata. Some 305 indeterminate centric diatoms were also frequently observed (in 20 samples) from May to December 306 in the oligohaline part of the estuary. The gradient in species richness was positively correlated with 307 the salinity gradient $(\mathrm{p}<0.001)$ with an average of 11 different taxonomic units per month observed 308 at site 1 , nine at site 3 , six at site 5 , and four at site 7 (Table 1 ). Thus, diatoms dominated the 309 community with a mean of $85 \%$ of diatom cells per sample. Per sample, between 400 and 108400 cells $\mathrm{L}^{-1}$ were estimated for diatoms, up to 15400 cells $\mathrm{L}^{-1}$ for dinoflagellates, and up to 6700 cells $\mathrm{L}^{-1}$ for the other eukaryote taxonomic units. Both the lowest and the highest values for diatoms were observed in May, at sites 1 and 7, respectively. The absence of dinoflagellates was often observed in the oligohaline part (sites 5 and 7) while high dinoflagellate abundance was observed in spring and summer in the polyhaline part with the highest value at site 5 in September. Dinoflagellates were more abundant than diatoms in spring and summer (Fig. 2).

\subsection{Pico- and nano-phytoplankton communities}

Two different populations of Cyanobacteria belonging to the genus Synechococcus were observed. These two populations, Syn_1 and Syn_2, could be distinguished from one another by their orange fluorescence, which is linked to their phycoerythrin content: population Syn_1 had higher phycoerythrin content than population Syn_2 (Fig. 4-A). While Syn_1 was observed over the entire study period, Syn_2 was only observed in April and from July to September (data not shown). 
325 (Fig. 2 \& Fig. 3) with the highest abundance $\left(1.5 \times 10^{4}\right.$ cells.L $\mathrm{L}^{-1}$ in the sub-surface layer and $2.5 \times 10^{4}$ 326 cells. $\mathrm{L}^{-1}$ close to the WSI) observed in January at site 1.

While two sub-populations of pico-eukaryotes were distinguished, the difference in SSC and

FL4 was not significant and consequently only one population of pico-eukaryotes corresponding to the sum of Pic-Euk_1 and Pico-Euk_2 abundances is discussed hereafter (Fig. 4-B). Pico-eukaryote cells were present throughout the year, except in July, and all along the salinity gradient. The highest pico-eukaryote abundance $\left(3.4 \times 10^{4}\right.$ cells. $\mathrm{L}^{-1}$ at both depths) was observed downstream (at sites $1 \&$ 2) in April close to the WSI and in May in the sub-surface layer (Fig. 2 \& 3). Pico-eukaryote abundances decreased from downstream to upstream over the course of the year.

Regarding nano-phytoplankton, six different populations of Cryptophyceae were identified. These six different populations were distinguished based on their specific fluorescence in the FLA and FL4 channels (Fig. 4-C). The sub-population crypto_3 was present in the Seine estuary throughout the year except in May. The five other sub-populations of Cryptophyceae were recorded sporadically along the salinity gradient in spring and summer. Abundances decreased from downstream to upstream over the course of the year. The highest values $\left(3.0 \times 10^{4}\right.$ cells. $\mathrm{L}^{-1}$ in the subsurface layer and $2.6 \times 10^{4}$ cells. $L^{-1}$ close to the WSI) were measured downstream at site 2 in June and July (Fig. 2 \& 3).

\subsection{EPS concentrations}

As a function of the different EPS, the S-EPS in the sub-surface layer, ranged between 0 and $39.54 \mathrm{mgGeq} \mathrm{L}^{-1}$ which represents $\sim 73 \%$ of the total EPS pool with the highest value recorded at site 5 in June, while B-EPS values ranged between 0.24 and $14.18 \mathrm{mgGeq}^{-1}$ representing $\sim 27 \%$ of the total EPS pool with the highest value recorded at site 3 in June. High values were recorded from March to July with the highest values recorded in the polyhaline zone (sites 2 to 7 ) while low values were recorded at all the sites during the rest of the year (Fig. 2). S-EPS and B-EPS were significantly 
correlated with the phytoplankton dynamics $\left(\mathrm{F}_{\mathrm{V}} / \mathrm{F}_{\mathrm{M}}, \mathrm{chl} a\right)$ (Tab. 2). Close to the WSI, S-EPS values ranged between 0 and $74.32 \mathrm{mgGeq} \mathrm{L}^{-1}$ and represented $\sim 67.75 \%$ of the total EPS pool with the highest value recorded at site 2 in May, while B-EPS values ranged between 0.23 and $17.11 \mathrm{mgGeq}$ $\mathrm{L}^{-1}$ and represented $\sim 32.25 \%$ of the total EPS pool with the highest value recorded at site 4 in June. Distribution was similar with high values recorded from March to July in the downstream zone while low values were recorded at all the sites during the rest of the year (Fig. 3). The carbon pool available from EPS in the Seine estuary was between 0.1 and $5.7 \mathrm{mgC} \mathrm{L}^{-1}$ in the sub-surface layer and between 0.1 and $33.2 \mathrm{mgC} \mathrm{L}^{-1}$ close to the WSI.

\subsection{TEP concentrations}

TEP concentrations ([TEP]) showed high spatial and temporal variability at both depths (Fig.

2). In the sub-surface layer, values ranged between 2.21 and $16.48 \mathrm{mgXGeq} \mathrm{L}^{-1}$ with a mean of 6.32 mgXGeq $L^{-1}$. The highest values were recorded in February at site 4 and the lowest value was recorded in May at site 1. High values were recorded from January to April and from October to December, while low values were recorded from April to October (Fig. 2). Close to the WSI, values ranged between 3.11 and $98.20 \mathrm{mgXGeq} \mathrm{L}^{-1}$ with a mean of $15.93 \mathrm{mgXGeq} \mathrm{L}^{-1}$ (Fig. 3). The highest value was recorded in December at site 8 and the lowest in May at site 2. Distribution was more variable with some patches. High values (> $20 \mathrm{mgXGeq} \mathrm{L}^{-1}$ ) were recorded in the low salinity zone (at sites 6 \& 8) from September to December and at site 8 in July and August, and low values in summer. At both depths, [TEP] were positively correlated with turbidity and SPM values and negatively correlated with biological parameters (Table 2). The available carbon pool from TEP in the Seine estuary ranged between 1.55 and $11.5 \mathrm{mgC} \mathrm{L}^{-1}$ in the sub-surface layer and between 2.2 and $68.7 \mathrm{mgC} \mathrm{L}^{-1}$ close to the WSI.

\subsection{Relationships between biological parameters and environmental variables}


Principal component analyses (PCA) were performed on the data set to explore the

376 relationships between biological and abiotic parameters (Fig. 5). The $1^{\text {st }}$ and $2^{\text {nd }}$ components 377 explained $65 \%$ of the total inertia for the sub-surface layer and $71 \%$ for the bottom layer. The first 378 principal components (PC1; $41 \%$ of variance in sub-surface and $52 \%$ close to the WSI) formed a 379 typical estuarine axis with parameters related to the inflow of marine waters such as salinity on the 380 left hand side of axis 1, and parameters related to freshwater inputs, such as $\mathrm{Si}$, DIN concentrations 381 or turbidity on the right hand side of axis 1 . The second principal component (PC2; $24 \%$ of variance 382 in surface and $19 \%$ close to the WSI) was strongly influenced by factors related to seasonal changes 383 such as irradiance and temperature. In sub-surface water, chl $a$ concentrations were positively 384 correlated with irradiance $(\mathrm{SCC}>0.36 ; \mathrm{p}<0.001 ; \mathrm{n}=96)$, temperature $(\mathrm{SCC}>0.43 ; \mathrm{p}<0.001, \mathrm{n}=$ $38596)$ and salinity ( $\mathrm{SCC}>0.35 ; \mathrm{p}<0.001 ; \mathrm{n}=96)$ while close to the WSI chl $a$ concentrations were 386 correlated principally with temperature $(\mathrm{SCC}>0.37 ; \mathrm{p}<0.001 ; \mathrm{n}=48)$. The phytoplankton 387 community were positively correlated with the salinity values and negatively with the nutrients 388 concentrations (N, Si). The correlations between TEP and EPS concentrations with the other 389 parameters are presented table 2. The PCA illustrate the high correlation between EPS and irradiance $390 \quad(\mathrm{SCC}>0.6 ; \mathrm{p}<0.001 ; \mathrm{n}=96)$.

higher light availability, lower flow, and lower turbidity than in winter) resulted in denser phytoplankton biomass. The high flow and resulting currents and the reduction in salinity, low light availability with high turbidity in winter drastically reduced population density and production. In this way, the annual cycle of phytoplankton in the Seine estuary is typical of temperate ecosystems. 
The dynamics and the high density of phytoplankton in terms of chla coincides with high species richness, high primary production (PP), and high productivity values (Morelle et al. 2018).

The Seine estuary thus seems to have a high PP with high species richness in the phytoplankton community $(\mathrm{p}<0.001$; Fig. 6). The richness and the abundance of phytoplankton decreased from downstream to upstream, possibly due to the dominance of marine species in the estuary and the decrease in salinity during the dilution process. Indeed, in the Seine estuary, most of the spatial structure of phytoplankton abundance, composition, or production can easily be linked with the dynamics of the environmental variables, particularly salinity. This hypothesis is in accordance with the large number of phytoplankton originate from high salinity water identified during this study. The Seine estuary thus appears to be mainly inhabited by marine phytoplankton whose species richness and abundance decreases with the salinity gradient. This distribution pattern appears to be 410 closely linked to the ecocline concept proposed by Attrill \& Rundle (2002) and already reported in 411 the Schelde estuary (Muylaert et al. 2009). The low frequency of freshwater species can be linked to 412 the limits of our sampling strategy, which was applied along the salinity gradient up to the MTZ. It is 413 widely accepted that freshwater species, which are mainly of riverine origin, cannot survive in the 414 MTZ. Thus, a succession of phytoplankton species acclimated to low light are observed in the MTZ 415 (Muylaert et al. 2000). These species are able to grow in highly turbid environments by reducing dark respiration rates, and increasing accessory pigments and chlorophyll a cell content to increase 417 the efficiency of their light harvesting complex (Muylaert et al. 2000). Moreover, in the Seine 418 estuary, the copepod Eurytemora affinis (Poppe, 1880) is widely distributed in the oligohaline part of 419 the estuary (up to $2 \times 10^{5}$ ind. $\mathrm{m}^{-3}$ ) and mainly feeds on phytoplankton of river origin (Cailleaud et al. 420 2007).

421 Thus, if the estuary is represented by a two-ecocline model, the marine ecocline was observed, and 422 the freshwater ecocline is located further upstream beyond the MTZ. This supports the view 
expressed by Cloern \& Dufford (2005) that the pelagic ecosystem of an estuary is an open system in which immigration and dispersal sustain community diversity.

The dinoflagellate assemblages were characterized by a few species: a spring peak (AprilMay) was dominated by Gonyaulax sp. and a summer peak (July to September) by Scripsiella sp., and Prorocentrum sp. . Apart from these two peaks, dinoflagellates were sparse in the water column. In the present study, diatoms formed the main component of the phytoplankton population, which could be due to their tolerance of the dynamic environmental conditions and euryhaline nature. Along the estuarine salinity gradient and over the course of the year, phytoplankton in both zones (downstream and upstream) were mainly dominated by Skeletonema sp., Nitzschia sp., and Paralia sulcata. These estuarine assemblages have already been described in the Pearl River estuary (Huang et al. 2004). Indeed, Skeletonema sp and Nitzschia sp are euryhaline and eurythermal species that can grow rapidly under eutrophic conditions (Huang et al. 2004). Neither was it not surprising to find $P$. sulcata as a dominant species because this diatom is widely distributed and is often found in temperate brackish to marine planktonic and benthic waters, in both littoral and sublittoral zones (McQuoid and Nordberg 2003). The high vertical mixing and resuspension in estuaries creates conditions that favor the occurrence of $P$. sulcata, especially because this species has a competitive advantage in low light conditions (Hobson and McQuoid 1997). Some other species were often observed in the downstream zone like Dytilum sp, Rhizoslenia sp, and Chaetoceros sp, which are known to be typical species of clear coastal or estuarine waters (Muylaert et al. 2000, 2009). It thus appears that the typical estuarine gradients (salinity, turbidity) play a fundamental role in the phytoplankton species community favoring the most competitive species under changes in salinity and light availability.

Because of their high surface to volume ratio, small cells grow much more efficiently than large cells in low light conditions (Kiorboe 1993) and are thus expected to be frequent in turbid systems like estuaries. In our study, no clear differences were found between the size-fractionated 
measurements, although observations of micro-phytoplankton revealed the strong presence of large

chain-forming diatoms. However, this study also provided observations of pico-nano phytoplankton

in the Seine estuary and revealed high abundances of up to $50.10^{3}$ cells. $\mathrm{L}^{-1}$ with a mean of $13.10^{3}$ cells.L $L^{-1}$ over the course of the year. Such high abundances could have a strong impact on the knowledge of the trophic network and on the carbon flow in estuarine systems. Spatially, abundances of pico-nano phytoplankton decreased from downstream to upstream probably due to the decrease in salinity and in light availability, which create conditions that are not optimal for the growth of photosynthetic organisms. A clear seasonal succession was observed for pico-nano phytoplankton with dominance of Synechococcus in winter (January to March), then dominance of pico-eukaryotes in spring (April to June), and dominance of Cryptophyceae in summer (July to September). The low abundance of Synechococcus could be explained by the fact that this cyanobacteria develops preferentially in the upper part of well-lit euphotic zones, which is not the case in an ecosystem as dynamic and turbid as an estuary (Partensky et al. 1999). The dominance of pico-eukaryotes in spring is in accordance with the results of previous studies that demonstrated the halotolerant marine, brackish, freshwater habitats (Klaveness 1988) and due to an either red or blue phycobiliprotein as a light harvesting complex for photosynthesis Cryptophyceae can acclimatize to estuarine primary production and should thus be further explored. 
The seasonal and spatial distribution of TEP is in accordance with our previous results at

473 daily scale in the Seine estuary (Morelle et al. 2017), which showed that the TEP were inversely

474 correlated with phytoplankton dynamics, and closely linked to resuspension processes. In this study,

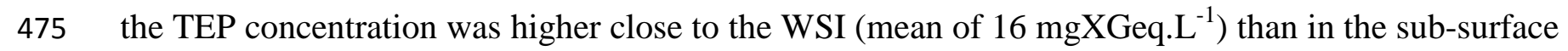

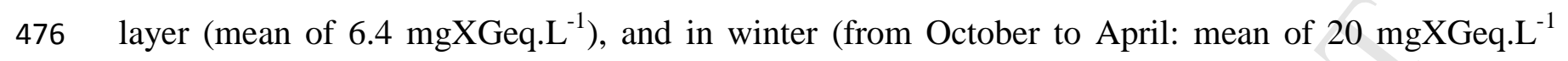

477 close to the WSI and $8 \mathrm{mgXGeq} \cdot \mathrm{L}^{-1}$ in the sub-surface layer) than in summer (from May to

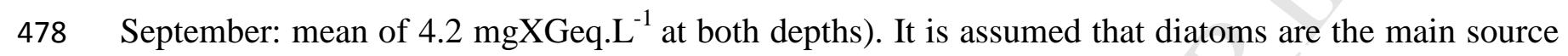

479 of TEP precursors and that their production ability depends on the composition of the community

480 (Passow and Alldredge 1994; Passow 2002). However, our results differ from those obtained by

481 Annane et al. (2015), who showed than Skeletonema sp., Thalassiosira sp., and Chaetoceros sp.

482 seems to be the main source of TEP in the St. Lawrence estuary due to a coincidence between the

483 highest TEP concentrations and the phytoplankton biomass peaks. Some studies have also shown

484 that dinoflagellates as Lepidodinium, Gymnodinium or Alexandrium can produce large amount of

485 TEP (Claquin et al. 2008; Villacorte et al. 2015). In the present study, these three genera were

486 observed in the Seine estuary throughout the year (Table 1) but their occurrence was not correlated

487 with TEP concentrations. Our results showed that the species most present at high TEP

488 concentrations were Paralia sulcata, Rhizosolenia imbricata and Nitzschia sp.. However, these

489 species were also present during periods with lower TEP concentrations, which allows us to

490 hypothesize that the occurrence of species known to be large producers of TEP is not sufficient to

491 explain the TEP dynamics in an ecosystem as dynamic as an estuary. Especially since the peak of

492 TEP producers can be time-lagged with respect to the peak of TEP due to polysaccharide production

493 processes rates or to diatom stress. This hypothesis is reinforced by the positive relationship we

494 found between [TEP] and [Si] and the negative relationship with diatom abundance (Table 2). In this

495 study, our results rather confirm that, in the Seine estuary, healthy phytoplankton produce less than

496 stressed or dying phytoplankton as already demonstrated in both field and laboratory studies (Liu and 
497 Buskey 2000; Ramaiah et al. 2001; Klein et al. 2011; Chowdhury et al. 2016), confirmed by the negative relationship between [TEP] and $\mathrm{F}_{\mathrm{V}} / \mathrm{F}_{\mathrm{M}}$ (Table 2). This study also confirms the previously demonstrated strong relationship between TEP and, SPM, turbulence and mixing (Beauvais et al. 2006; Malpezzi et al. 2013; Morelle et al. 2017)which favor TEP production by diatoms but also disruption of aggregates in the water column.

In addition to confirming that TEP dynamics was inversely correlated with phytoplankton

\subsection{EPS dynamics and distribution in relation with biological, physical and chemical} processes

In contrast to the distribution of TEP, EPS distribution enabled us to make additional observations compared with our previous results at daily scale in the Seine estuary (Morelle et al. 2017). Indeed, the daily scale used in the winter and summer season showed values lower than 10 mgGeq. $\mathrm{L}^{-1}$ but in this study, an increase in EPS concentrations in the Seine estuary from April to July with values higher than $10 \mathrm{mgGeq} \cdot \mathrm{L}^{-1}$ (up to $51.5 \mathrm{mgGeq} \cdot \mathrm{L}^{-1}$ in the sub-surface layer and 83 mgGeq. L $^{-1}$ close to the WSI, S-EPS and B-EPS taken together) was observed. Our results revealed a significant negative relationship between [TEP] and [S-EPS] or [B-EPS] (Table 2) suggesting that different factors influence their production. The production of carbohydrates by phytoplankton is 521 known to be highly variable and to depend on the species, growth stage and environmental 
conditions (Alldredge 1999; Penna et al. 1999). Phosphorus limitation (Alcoverro et al. 2000; Staats

et al. 2000) and, for some species, nitrogen limitation (Granum et al. 2002) can cause an increase in

photosynthetic extracellular release. In this study, the most frequent species observed during the increase in EPS were Skeletonema sp, present from February to August, and Nitzschia sp present throughout the year. Therefore, Skeletonema sp, which is known to produce large quantities of EPS (Urbani et al. 2005) could be responsible for the spring increase in EPS. Moreover, previous studies showed that a reduction in inorganic phosphorus content triggers the production of polysaccharides by different species, particularly Skeletonema sp (Shniukova and Zolotareva 2015). This result is in agreement with a decrease in P concentration from April to July in the downstream zone of the Seine estuary (Morelle et al. 2018) reinforced by the negative relationship with $\mathrm{P}$ concentration and the positive relationship with diatoms observed for S-EPS or B-EPS concentrations (Table 2). However, the positive relationship between S-EPS and Cryptophyceae abundance observed at both depths (Table 2) also suggests a contribution of pico/nano-phytoplankton to the pools of soluble carbohydrates measured. This hypothesis should be tested by an in vitro study on the possible production and excretion of EPS by Cryptophyceae. The concentrations of EPS measured in this study also confirmed the large proportion of the carbon pool available in the form of EPS which represented up to $30 \mathrm{mgC} . \mathrm{L}^{-1}$ from S-EPS and up to $7 \mathrm{mgC} . \mathrm{L}^{-1}$ from B-EPS.

\section{Conclusion}

This is the first description of the structure of the phytoplankton community along the salinity 542 gradient of the Seine estuary, and revealed the notable contribution of marine species, thus 543 confirming the ecocline concept. Moreover, the pico/nano-phytoplankton analysis showed in the 544 present study the contribution of smaller size-class (pico- and nano-phytoplankton) to the 545 phytoplankton biomass in the system which suggests a potential contribution of this compartment to 546 primary production. Our results confirm the importance of the TEP and EPS forms in the carbon 
pool available for the trophic network, since up to $69 \mathrm{mgC} . \mathrm{L}^{-1}$ from TEP, up to $30 \mathrm{mgC} . \mathrm{L}^{-1}$ from S-

548 EPS, and up to $7 \mathrm{mgC.L}{ }^{-1}$ from B-EPS were measured. Different dynamics between carbon excreted pools (TEP, EPS) were identified: TEP distribution was mainly related to physical factors

(hydrodynamics, MTZ formation and sediment resuspension) and appears to be produced by stressed

or dying phytoplankton, while EPS appears to be excreted during the phytoplankton spring bloom.

Soluble and bound EPS appears to be related to the occurrence of Skeletonema $s p$ and

Cryptophyceae, but the role of EPS and TEP in microbial loop and trophic transfer remained poorly

known. A significant relationship between primary production and species richness was observed in

this work, but further investigations are required to propose more general concepts regarding the relationship between community structure and carbon fluxes and

\section{Acknowledgments}

We acknowledge the assistance of Mathieu Filoche and Marilyne Guillamin in flow

cytometery analysis and Fanny Papelard in TEP analysis. We also thank the other members of Ifremer (Franck Maheux, Olivier Pierre-Duplessix, Benjamin Simon, Philippe Riou and Emilie

Rabiller) for their participation in data acquisition. This study was financed by the GIP Seine-Aval 5 program in the framework of the PROUESSE Project (SAV2013-PROUESSE-1).

\section{References}

Alcoverro, T., E. Conte, and L. Mazzella. 2000. Production of mucilage by the adriatic epipelic diatom Cylindrotheca closterium (Bacillariophyceae) under nutrient limitation. Journal of Phycology 36: 1087-1095.

Alldredge, A. L. 1999. The potential role of particulate diatom exudates in forming nuisance mucilaginous scums. Annali dell'Istituto Superiore di Sanita 35: 397-400.

Alldredge, A. L., U. Passow, and B. E. Logan. 1993. The abundance and significance of a class of large, transparent organic particles in the ocean. Deep-Sea Research Part I 40: 1131-1140.

Annane, S., L. St-Amand, M. Starr, E. Pelletier, and G. A. Ferreyra. 2015. Contribution of transparent exopolymeric particles (TEP) to estuarine particulate organic carbon pool. Marine Ecology Progress Series 529: 17-34.

Attrill, M. J., and S. D. Rundle. 2002. Ecotone or ecocline: Ecological boundaries in estuaries. Estuarine, Coastal and Shelf Science 55: 929-936. 
Beauvais, S., M. L. Pedrotti, J. Egge, K. Iversen, and C. Marrasé. 2006. Effects of turbulence on TEP dynamics under contrasting nutrient conditions: Implications for aggregation and sedimentation processes. Marine Ecology Progress Series 323: 47-57.

Bhaskar, P. V, and N. B. Bhosle. 2005. Microbial extracellular polymeric substances in marine biogeochemical processes. Current Science 88.

Brenon, I., and P. Le Hir. 1999. Modelling the Turbidity Maximum in the Seine Estuary ( France ): Identification of Formation. 525-544.

Cai, W.-J. 2011. Estuarine and Coastal Ocean Carbon Paradox: $\mathrm{CO}_{2}$ Sinks or Sites of Terrestrial Carbon Incineration? Annual Review of Marine Science 3: 123-145.

Cailleaud, K., J. Forget-Leray, S. Souissi, S. Lardy, S. Augagneur, and H. Budzinski. 2007. Seasonal variation of hydrophobic organic contaminant concentrations in the water-column of the Seine Estuary and their transfer to a planktonic species Eurytemora affinis (Calanoïd, copepod). Part 2: Alkylphenol-polyethoxylates. Chemosphere 70: 281-287.

Chowdhury, C., N. Majumder, and T. K. Jana. 2016. Seasonal distribution and correlates of transparent exopolymer particles (TEP) in the waters surrounding mangroves in the Sundarbans. Journal of Sea Research 112: 65-74.

Claquin, P., I. Probert, S. Lefebvre, and B. Veron. 2008. Effects of temperature on photosynthetic parameters and TEP production in eight species of marine microalgae. Aquatic Microbial Ecology 51: 1-11.

Cloern, J., and R. Dufford. 2005. Phytoplankton community ecology: Principles applied in San Francisco Bay. Marine Ecology Progress Series 285: 11.

Cloern, J. E., S. Q. Foster, and a. E. Kleckner. 2014. Phytoplankton primary production in the world's estuarine-coastal ecosystems. Biogeosciences 11: 2477-2501.

Cortelezzi, A., A. R. Capítulo, L. Boccardi, and R. Arocena. 2007. Benthic assemblages of a temperate estuarine system in South America: Transition from a freshwater to an estuarine zone. Journal of Marine Systems 68: 569-580.

Corzo, A., S. Rodriguez-Galvez, L. Lubian, P. Sangra, A. Martinez, and J. A. Morillo. 2005. Spatial distribution of transparent exopolymer particles in the Bransfield Strait, Antarctica. Journal of Plankton Research 27: 635-646.

Decho, A. W. 1990. Microbial exopolymer secretions in ocean environments: their role(s) in food webs and marine processes. Oceanogr. Mar. Annu. Rev. 28: 73-153.

Decho, A. W. 2000. Microbial biofilms in intertidal systems: an overview. Cont. Shelf Res. 20: 1257-1273.

Dubois, M., K. A. Gilles, J. K. Hamilton, Pa. Rebers, and F. Smith. 1956. Colorimetric method for determination of sugars and related substances. Analytical chemistry 28: 350-356.

Engel, A., and U. Passow. 2001. Carbon and nitrogen content of transparent exopolymer particles (TEP) in relation to their Alcian Blue adsorption. Marine Ecology Progress Series 219: 1-10.

Etcheber, H., A. Taillez, G. Abril, J. Garnier, P. Servais, F. Moatar, and M. V. Commarieu. 2007. Particulate organic carbon in the estuarine turbidity maxima of the Gironde, Loire and Seine estuaries: Origin and lability. Hydrobiologia 588: 245-259.

Even, S., J. M. Mouchel, P. Servais, N. Flipo, M. Poulin, S. Blanc, M. Chabanel, and C. Paffoni. 2007. Modelling the impacts of Combined Sewer Overflows on the river Seine water quality. Science of the Total Environment 375: 140-151.

Garcia, C. M. 2002. Hydrodynamics and the spatial distribution of plankton and TEP in the Gulf of Cadiz (SW Iberian Peninsula). Journal of Plankton Research 24: 817-833.

Garnier, J., G. Billen, J. Némery, and M. Sebilo. 2010. Transformations of nutrients (N, P, Si) in the turbidity maximum zone of the Seine estuary and export to the sea. Estuarine, Coastal and Shelf Science 90: 129-141.

Granum, E., S. Kirkvold, and S. M. Myklestad. 2002. Cellular and extracellular production of carbohydrates and amino acids by the marine diatom Skeletonema costatum: Diel variations and 
effects of N depletion. Marine Ecology Progress Series 242: 83-94.

Hammer, A., R. Schumann, and H. Schubert. 2002. Light and temperature acclimation of Rhodomonas salina ( Cryptophyceae ): photosynthetic performance Light and temperature acclimation of Rhodomonas salina ( Cryptophyceae ): photosynthetic performance. Aquatic Microbial Ecology 29: 287-296.

Hobson, L. A., and M. R. McQuoid. 1997. Temporal variations among planktonic diatom asseblages in a turbulent environment of the southern Strait of Georgia, British Columbia, Canada. Marine Ecology Progress Series 150: 263-274.

Huang, L., W. Jian, X. Song, X. Huang, S. Liu, P. Qian, K. Yin, and M. Wu. 2004. Species diversity and distribution for phytoplankton of the Pearl River estuary during rainy and dry seasons. Marine Pollution Bulletin 49: 588-596.

Kiorboe, T. 1993. Turbulence, phytoplankton cell size, and the structure of pelagic food webs. Advances in Marine Biology 29: 2-72.

Klaveness, D. 1988. Ecology of the Cryptomonadida: a first review. Growth and reproductive strategies of freshwater phytoplankton. Cambridge University Press, Cambridge 105-133.

Klein, C., P. Claquin, P. Alexandrine, C. Napoléon, B. Le Roy, and B. Véron. 2011. Dynamics of soluble extracellular polymeric substances and transparent exopolymer particle pools in coastal ecosystems. Marine Ecology Progress Series 427: 13-27.

Legendre, L., and R. B. Rivkin. 2002. Fluxes of carbon in the upper ocean: Regulation by food-web control nodes. Marine Ecology Progress Series 242: 95-109.

Lionard, M., K. Muylaert, A. Hanoutti, T. Maris, M. Tackx, and W. Vyverman. 2008. Inter-annual variability in phytoplankton summer blooms in the freshwater tidal reaches of the Schelde estuary (Belgium). Estuarine, Coastal and Shelf Science 79: 694-700.

Liu, H., and E. J. Buskey. 2000. Hypersalinity Enhances the Production of Extracellular Polymeric. Production 77: 71-77.

Lorenzen, C. J. 1966. A method for the continuous measurement of in vivo chlorophyll concentration. Deep Sea Research and Oceanographic Abstracts 13: 223-227.

Lund, J. W. G., C. Kipling, and E. D. Le Cren. 1958. The inverted microscope method of estimating algal numbers and the statistical basis of estimations by counting. Hydrobiologia 11: 143-170.

Van Der Maarel, E. 1990. Ecotones and ecoclines are different van. journal of vegetation Science $135-138$.

Malpezzi, M. A., L. P. Sanford, and B. C. Crump. 2013. Abundance and distribution of transparent exopolymer particles in the estuarine turbidity maximum of Chesapeake Bay. Marine Ecology Progress Series 486: 23-35.

Marie, D., F. Partensky, D. Vaulot, and C. Brussaard. 1999. Enumeration of phytoplankton, bacteria, and viruses in marine samples. Current protocols in cytometry 11.

Marinov, I., S. C. Doney, and I. D. Lima. 2010. Response of ocean phytoplankton community structure to climate change over the 21st century: Partitioning the effects of nutrients, temperature and light. Biogeosciences 7: 3941-3959.

McQuoid, M. R., and K. Nordberg. 2003. The diatom Paralia sulcata as an environmental indicator species in coastal sediments. Estuarine, Coastal and Shelf Science 56: 339-354.

Morelle, J., M. Schapira, and P. Claquin. 2017. Dynamics of phytoplankton productivity and exopolysaccharides (EPS and TEP) pools in the Seine Estuary (France, Normandy) over tidal cycles and over two contrasting seasons. Marine Environmental Research , doi:https://doi.org/10.1016/j.marenvres.2017.09.007

Morelle, J., M. Schapira, F. Orvain, P. Riou, P. J. Lopez, O. Pierre-Duplessix, E. Rabiller, F. Maheux, B. Simon, and P. Claquin. 2018. Annual Phytoplankton Primary Production Estimation in a Temperate Estuary by Coupling PAM and Carbon Incorporation Methods. Estuaries and Coasts 1-19.

Muylaert, K., K. Sabbe, and W. Vyverman. 2000. Spatial and temporal patterns of phytoplankton 
communities in a freshwater tidal estuary. Estuarine, Coastal and Shelf Science 50: 673-687.

Muylaert, K., K. Sabbe, and W. Vyverman. 2009. Changes in phytoplankton diversity and community composition along the salinity gradient of the Schelde estuary (Belgium/The Netherlands). Estuarine, Coastal and Shelf Science 82: 335-340.

Olson, R. J., E. R. Zettler, and M. D. DuRand. 1993. Phytoplankton analysis using flow cytometry. Handbook of methods in aquatic microbial ecology 175-186.

Orvain, F., M. De Crignis, K. Guizien, S. Lefebvre, C. Mallet, E. Takahashi, and C. Dupuy. 2014. Tidal and seasonal effects on the short-term temporal patterns of bacteria, microphytobenthos and exopolymers in natural intertidal biofilms (Brouage, France). Journal of Sea Research

Pan, L. A., L. H. Zhang, J. Zhang, J. M. Gasol, and M. Chao. 2005. On-board flow cytometric observation of picoplankton community structure in the East China Sea during the fall of different years. FEMS Microbiology Ecology 52: 243-253.

Partensky, F., J. Blanchot, and D. Vaulot. 1999. Differential distribution and ecology of Prochlorococcus and Synechococcus in oceanic waters : a review. Bulletin de l'Institut océanographique 19: 457-475.

Passow, U. 2002. Transparent exopolymer particles (TEP) in aquatic environments. Progress in Oceanography 55: 287-333.

Passow, U., and A. L. Alldredge. 1994. Distribution, size and bacterial colonization of transparent exopolymer particles (TEP) in the ocean. Marine Ecology Progress Series 185-198.

Passow, U., and A. L. Alldredge. 1995. A dye-binding assay for the spectrophotometric measurement of transparent exopolymer particles (TEP). Limnology and Oceanography 40: 1326-1335.

Passow, U., R. F. Shipe, A. Murray, D. K. Pak, M. A. Brzezinski, and A. L. Alldredge. 2001. The origin of transparent exopolymer particles (TEP) and their role in the sedimentation of particulate matter. Continental Shelf Research 21: 327-346.

Penna, a, S. Berluti, N. Penna, and M. Magnani. 1999. Influence of nutrient ratios on the extracellular polysaccharide production by marine diatoms from the Adriatic Sea. Journal Of Plankton Research 21: 1681-1690.

Ramaiah, N., T. Yoshikawa, and K. Furuya. 2001. Temporal variations in transparent exopolymer particles (TEP) associated with a diatom spring bloom in a subarctic ria in Japan. Marine Ecology Progress Series 212: 79-88.

Schapira, M., M.-J. Buscot, T. Pollet, S. C. Leterme, and L. Seuront. 2010. Distribution of picophytoplankton communities from brackish to hypersaline waters in a South Australian coastal lagoon. Saline systems 6: 2 .

Shniukova, E. I., and E. K. Zolotareva. 2015. Diatom Exopolysaccharides: a Review. International Journal on Algae 17: 50-67.

Staats, N., L. J. Stal, and L. R. Mur. 2000. Exopolysaccharide production by the epipelic diatom Cylindrotheca closterium: Effects of nutrient conditions. Journal of Experimental Marine Biology and Ecology 249: 13-27.

Trigueros, J. M., and E. Orive. 2000. Tidally driven distribution of phytoplankton blooms in a shallow, macrotidal estuary. Journal of Plankton Research 22: 969-986.

Urbani, R., E. Magaletti, P. Sist, and A. M. Cicero. 2005. Extracellular carbohydrates released by the marine diatoms Cylindrotheca closterium, Thalassiosira pseudonana and Skeletonema costatum: Effect of P-depletion and growth status. Science of the Total Environment 353: 300-306.

Vaulot, D., C. Courties, and F. Partensky. 1989. A simple method to preserve oceanic phytoplankton for flow cytometric analyses. Cytometry 10: 629-635.

Vigil, P., P. D. Countway, J. Rose, D. J. Lonsdale, C. J. Gobler, and D. A. Caron. 2009. Rapid shifts in dominant taxa among microbial eukaryotes in estuarine ecosystems. Aquatic Microbial Ecology 54: 83-100.

Villacorte, L. O., Y. Ekowati, H. N. Calix-Ponce, J. C. Schippers, G. L. Amy, and M. D. Kennedy. 
2015. Improved method for measuring transparent exopolymer particles (TEP) and their precursors infresh and saline water. Water Research 70: 300-312.

Wang, Z. B., M. C. J. L. Jeuken, H. Gerritsen, H. J. De Vriend, and B. A. Kornman. 2002.

Morphology and asymmetry of the vertical tide in the Westerschelde estuary. Continental Shelf Research 22: 2599-2609.

Wetz, M. S., M. C. Robbins, and H. W. Paerl. 2009. Transparent exopolymer particles (TEP) in a river-dominated estuary: Spatial-temporal distributions and an assessment of controls upon TEP formation. Estuaries and Coasts 32: 447-455. 
Figure 1. Map of the Seine estuary (Longitude: 0.2327, latitude: 49.4326 (WGS84) - Normandy, France) showing the study area. Poses is the upper limit of tidal propagation. The sampling transect from site 1 to site 8 followed the salinity gradient from the euhaline zone (Site 1- L: 0.1116, 1: 49.4335) to the oligohaline zone (site 8 - L: 0.5149, 1: 49.4841). The sites were sampled monthly throughout 2015.

Figure 2. Variations in the parameters in the sub-surface layer $(1 \mathrm{~m}$ under the surface) of the Seine estuary from January to December, 2015. With total, small cell and large cell chl $a$ concentrations $\left(\mu \mathrm{gchl} a . \mathrm{L}^{-1}\right)$; S-EPS, B-EPS $\left(\mathrm{mgG} . \mathrm{L}^{-1}\right)$ and TEP concentrations (mgXGeq.L $\left.\mathrm{L}^{-1}\right)$; Synechococcus, Pico-eukaryotes, Cryptophyceae, diatom and dinoflagellate abundance (cells. $\mathrm{L}^{-1}$ ). The dinoflagellate:diatom abundance ratio is also given. Values were previously smoothed using the Loess non-parametric regression method.

Figure 3. Variations in the parameters close to the water/sediment interface $(1 \mathrm{~m}$ above the sediment $)$ in the Seine estuary from January to December, 2015. With total, small cell and large cell chl $a$ concentrations $\left(\mu \mathrm{gchl} l \cdot \mathrm{L}^{-1}\right)$; S-EPS, B-EPS (mgG.L ${ }^{-1}$ ) and TEP concentrations (mgXGeq.L ${ }^{-1}$ ); and Synechococcus, Pico-eukaryotes, and Cryptophyceae abundances $\left(\right.$ cells. $\mathrm{L}^{-1}$ ). Values were previously smoothed using the Loess non-parametric regression method.

Figure 4. Cytometric signatures of the different populations observed in 2015 along the Seine estuary. A $1 \mu \mathrm{m}$ selffluorescent latex marble was added to each sample as a size and fluorescence reference. The graphs show the FL3 median (phycoerythrin), FL4 median (chlorophyll) and SSC median (size). With the two Synechococcus populations (A), the two pico-eukaryote populations that were not significantly differentiated (B) and the six Cryptophyceae populations (C).

Figure 5. Representation of Principal Component Analysis (PCA) using the abiotic parameters as qualitative variables (Irradiance $\left(\mathrm{J} \mathrm{cm}^{2}\right)$, flow $\left(\mathrm{m}^{3} \mathrm{~s}^{-1}\right)$, temperature $\left({ }^{\circ} \mathrm{C}\right)$, salinity $(\mathrm{PSU}), \mathrm{SPM}\left(\mathrm{g} \mathrm{L}^{-1}\right)$ and nutrients $\left.(\mu \mathrm{mol} \mathrm{L})^{-1}\right)$ : DIN, $\mathrm{P}$ and $\mathrm{Si}$ ) and the biological parameters as quantitative variables (total chl $a$ (T.Chla) and chl $a$ of small and large

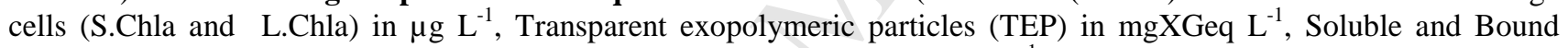
exopolymeric substances (S.EPS and B.EPS) concentrations in $m g E P S ~ \mathrm{~L}^{-1}$ and the abundance of phytoplankton community (Synechococcus (Syn), Cryptophyceae (crypto), Pico-eukaryotes (Picoeuk), diatoms (Diat.) and dinoflagellates (Dino.) in cells $\left.\mathrm{L}^{-1}\right)$ ). The sub-surface water was represent in the left panel and the water sediment interface in the right panel.

Figure 6. Primary production as a function of the species richness of the Seine estuary. All the spatial (sites 1, 3, 5 \& 7) and temporal (from January to December) data were used in this plot. Species richness was calculated as a function of the microscopic observations made in this study (table 1) and expressed in $\log _{10}+1$. The primary production data $\left(\mathrm{gC} . \mathrm{m}^{-2} \cdot \mathrm{d}^{-1}\right)$ are detailed in Morelle et al. (submitted). The dynamic fit was performed on SigmaPlot 12.5 after 200 iterations of fits and the final equation was $\mathrm{PP}=\mathrm{e}^{2.5 \times \mathrm{SR}}\left(\mathrm{p}<0.001 ; \mathrm{R}^{2}=0.35\right)$. 


\section{ACCEPTED MANUSCRIPT}

Table 1. Presence and absence of the diatoms, dinoflagellates and other algal group taxa observed by optic microscopy from January to December 2015 in the sub-surface layer at sites 1, 3, 5 and 7. $X X X$ represent unidentified taxonomic units.

\begin{tabular}{|c|c|c|c|c|c|c|c|c|c|c|c|c|c|}
\hline Month & January & February & March & April & May & June & July & August & September & October & November & December & \\
\hline Sites & 1357 & 1357 & 13357 & 1357 & 1357 & 1357 & $\begin{array}{r}1357 \\
\end{array}$ & 1357 & 1357 & 1357 & 1357 & 1357 & SUM \\
\hline & & & & & & Diatoms & & & & & & & \\
\hline Biddulphiales & $1--1$ & -1 & $111-$ & $1-11$ & $\cdots$ & $-\cdots$ & $\cdots$ & $\cdots$ & $\cdots$ & $\cdots$ & $\ldots$ & $\cdots$ & 8 \\
\hline Thalassiosiraceae sp. & $\cdots$ & $\cdots$ & $-1-$ & $\cdots$ & $\cdots$ & $\cdots$ & $\cdots$ & $\cdots$ & $-1-$ & $\cdots-$ & $\cdots$ & $\cdots$ & $2^{2}$ \\
\hline asterionella sp. & $-\cdots$ & $-\cdots-$ & $11--$ & $-\cdots$ & $-\cdots-$ & $-\cdots-$ & $-\cdots-$ & $\cdots$ & $\cdots$ & $\cdots$ & $\ldots$ & $\cdots$ & \\
\hline Cerataulina & $\cdots$ & $-\quad--$ & 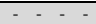 & $-\ldots$ & $-\ldots-$ & $-1-$ & $1 \cdots$ & $\cdots$ & $\cdots$ & $\cdots$ & $\cdots$ & $\cdots$ & 2 \\
\hline Chaetoceros & $1-1-$ & $\ldots$ & $\ldots$ & $\ldots$ & $1-\cdots$ & $\begin{array}{llll}1 & 1 & - \\
\end{array}$ & $\ldots$ & $\begin{array}{llll}1 & 1 & 1 & - \\
\end{array}$ & $1-\cdots$ & $\begin{array}{llll}1 & 1 & 1 & - \\
\end{array}$ & $\begin{array}{llll} & 1 & - \\
\end{array}$ & $\ldots$ & 14 \\
\hline Detonula sp & $\ldots$ & $\ldots-$ & $\ldots$ & $-1-$ & $-1=$ & $-\ldots 1$ & $\ldots$ & $\cdots$ & $\cdots$ & $\cdots-$ & $\ldots$ & $\ldots$ & \\
\hline Ditylum sp. & $-\cdots$ & $-\quad-\quad-$ & $1--$ & $11--$ & $1--$ & $\begin{array}{lll} & 1 & - \\
\end{array}$ & $-11=$ & $1 \quad 1-$ & $\cdots$ & $1-\cdots$ & $\ldots-$ & $\cdots$ & 11 \\
\hline Laude & $1 \ldots$ & $\ldots$ & $1 \ldots$ & $\ldots$ & $\ldots$ & - - - & & $\cdots$ & $\ldots$ & $\ldots-$ & $\ldots$ & $\ldots$ & 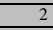 \\
\hline Leptocylindrus & $\ldots$ & $-1-$ & $\ldots-$ & 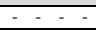 & $\ldots-$ & $-\cdots$ & $111-$ & $-1-$ & $-1-$ & $-\cdots$ & $\ldots$ & $\cdots$ & 5 \\
\hline Licmor & $\cdots$ & $-\cdots$ & $-1-$ & $\cdots$ & $\cdots$ & $-\cdots-1$ & $\ldots$ & $\cdots$ & $\cdots$ & $\cdots-$ & $\ldots-$ & $\cdots$ & \\
\hline Naviculaceae $s_{t}$ & $1-1-$ & $-\ldots 1$ & $-1-$ & $-\cdots$ & - - - & ---1 & $-1-$ & $\cdots$ & $111-$ & $-\cdots$ & $1 \ldots$ & $1-$ & 10 \\
\hline Nitzschia sp. & $\begin{array}{llll}1 & 1 & 1\end{array}$ & $-1 \quad 1 \quad 1 \quad 1$ & $-11-$ & $\begin{array}{llll} & 1 & 1 & -\end{array}$ & $\begin{array}{llll}1 & 1 & 1\end{array}$ & $\begin{array}{llll} & 1 & 1 & -\end{array}$ & 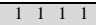 & $\begin{array}{llll} & 1 & 1 & 1\end{array}$ & $1--$ & $11-$ & $\begin{array}{lllll} & 1 & 1 & 1 & 1\end{array}$ & $\cdots$ & 32 \\
\hline Odor & $\cdots$ & 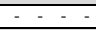 & $\cdots$ & $-1-$ & $\cdots$ & $1 \cdots$ & $\cdots$ & $1 \cdots$ & $\cdots$ & $1-\cdots$ & $\begin{array}{llll} & 1 & 1 & 1 \\
\end{array}$ & $1-\cdots$ & 8 \\
\hline $\operatorname{cosc}$ & $\cdots$ & $\ldots-$ & $\ldots$ & $\ldots$ & $\cdots$ & 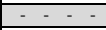 & $\ldots$ & $1 \ldots$ & $\cdots$ & $\cdots-$ & $\ldots$ & $\cdots$ & 1 \\
\hline & $\ldots$ & $\cdots$ & $\cdots$ & $\cdots$ & $\cdots$ & $\ldots$ & $\cdots$ & $\cdots$ & $\cdots$ & $-1-$ & $\ldots$ & $\cdots$ & \\
\hline Plagi & $\ldots$ & $\ldots-$ & $\ldots$ & $1-\cdots$ & $\ldots$ & $1-\cdots$ & $\ldots-$ & $\cdots$ & $\ldots-$ & $-\cdots$ & $\ldots-$ & $\ldots-$ & 2 \\
\hline Pleur & $-\quad-\quad-$ & $-11-$ & $1--1$ & $--\quad-$ & $11--$ & \begin{tabular}{llll|} 
& - & 1 & 1
\end{tabular} & $-11-$ & $1 \ldots$ & $-\ldots$ & $---\quad-$ & $1--$ & 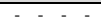 & 12 \\
\hline Gyro & $\cdots$ & $-11-$ & $1--1$ & $\cdots$ & $\begin{array}{lll}1 & 1 & - \\
\end{array}$ & $-1-11$ & $-11-$ & $1 \ldots$ & $\cdots$ & $\cdots-$ & $1 \cdots$ & $\cdots$ & 12 \\
\hline Psen & $\ldots$ & $\cdots$ & $\cdots$ & $\cdots$ & $\ldots$ & $11-1$ & $\ldots$ & $-1-$ & $\ldots$ & $1 \cdots$ & $\cdots$ & $1 \cdots$ & 6 \\
\hline Raph & $-\cdots$ & $-\ldots 1$ & $-\cdots$ & $--1=$ & $-\cdots$ & $-\cdots$ & $-\cdots$ & $\cdots$ & $-\cdots$ & $-\cdots$ & $-\cdots$ & $-\cdots$ & \\
\hline Skele & $\ldots$ & $\begin{array}{llll}1 & 1 & 1 & -\end{array}$ & $\begin{array}{lllll} & 1 & 1 & 1 & 1\end{array}$ & $11-1$ & $11-$ & $\begin{array}{lllll} & 1 & 1 & 1\end{array}$ & $11 \ldots$ & $\begin{array}{llll} & 1 & 1 & 1\end{array}$ & $1-$ & $1-$ & $1 \ldots$ & $\ldots-$ & 25 \\
\hline Guin & 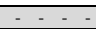 & $-1-$ & $-\cdots$ & $\cdots$ & $11-$ & $-1-$ & $-\ldots$ & $\cdots$ & $1-1-$ & $-\cdots$ & $-1-$ & $\cdots$ & 7 \\
\hline Guin & $-\quad-\quad-$ & $-\quad-\quad-$ & ---- & $1--$ & ---- & $-\quad-\quad-\quad-$ & $-\quad-\quad--$ & $-\cdots$ & $--\quad-$ & $--\quad-$ & $-\quad-\quad--$ & $-\quad-\quad-$ & \\
\hline Laud & $-\cdots$ & $-\cdots$ & $-\cdots$ & $-\cdots$ & $-\cdots$ & - - - - & $-1-$ & $\cdots$ & $\cdots$ & $\cdots$ & $\ldots-$ & $\cdots$ & 1 \\
\hline Dact & $\cdots$ & $-\ldots$ & $\cdots$ & $\cdots$ & $\cdots$ & $-1-$ & $\cdots$ & $\cdots$ & $\cdots$ & $\cdots-$ & $\cdots$ & $\cdots$ & \\
\hline & $-\quad-\quad-$ & $-\quad-\quad-$ & $--\quad-$ & $-\quad--$ & $-\quad-\quad-$ & $\cdots$ & $1 \cdots$ & $\cdots$ & $\begin{array}{lll}1 & 1-\end{array}$ & $\cdots-$ & $\cdots$ & $\cdots$ & 3 \\
\hline Paro & 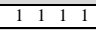 & $\begin{array}{l}-111 \\
\end{array}$ & $1 \cdots$ & $-111-$ & $\cdots$ & \begin{tabular}{|llll} 
& 1 & -1 \\
\end{tabular} & $1 \cdots$ & $\cdots$ & $1-1-$ & $-1-$ & $\begin{array}{llll} & 1 & 1 & - \\
\end{array}$ & $\begin{array}{llll} & 1 & - \\
\end{array}$ & 23 \\
\hline Rhiz & $-\cdots$ & $-\ldots 1$ & $11-$ & $11-$ & $11-$ & $111-$ & $1-1-$ & $\cdots$ & $-\cdots$ & $\begin{array}{llll} & 1 & 1 & -\end{array}$ & $\begin{array}{lllll} & 1 & 1 & 1 & 1\end{array}$ & $-1-$ & 20 \\
\hline & $-1-$ & $-\cdots$ & $\cdots$ & $\cdots$ & $\cdots$ & $-1-$ & $-\cdots$ & $\therefore-$ & $\cdots$ & $\cdots$ & $\cdots$ & $-\cdots$ & 2 \\
\hline That & $\cdots$ & $\cdots$ & $\cdots$ & $1 \cdots$ & $-1-$ & $1 \ldots$ & $1 \ldots$ & $-1-$ & $-1-$ & $\cdots$ & $11 \ldots$ & $-1-$ & 9 \\
\hline & --- & $--1-$ & $--\cdots$ & $-\cdots$ & --- & $\cdots-$ & $-\cdots$ & $\cdots$ & $\cdots$ & $-\cdots$ & $-\cdots$ & $\cdots$ & 1 \\
\hline Thal & $\ldots$ & - - - & $\cdots$ & $-1-$ & $\cdots$ & $-\cdots$ & $\ldots$ & $\cdots$ & $\cdots$ & 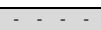 & $\ldots$ & $\cdots$ & \\
\hline Thal & $-\quad--$ & $-\cdots$ & $-\cdots$ & $-1--$ & $-\cdots-$ & $-\cdots$ & $-\quad--$ & $\cdots$ & $-\cdots-$ & $-\cdots-$ & $-\ldots-$ & --- & \\
\hline Euca & $-\cdots$ & $-\quad--$ & $-\cdots$ & $-\cdots$ & $-\cdots$ & $11-$ & $-\ldots$ & $\cdots$ & $1--$ & --- & $-\quad-$ & $-1-$ & 4 \\
\hline $\mathrm{Meu}$ & $-\cdots$ & $-\cdots$ & $-\cdots$ & $-\cdots$ & $-\cdots$ & $-\cdots-$ & $-\cdots$ & $\cdots$ & $-\cdots$ & $-\cdots$ & $1-$ & $-\cdots-$ & \\
\hline & $\cdots$ & $\ldots$ & $\ldots$ & $\ldots$ & $\ldots$ & $\ldots-$ & $\ldots$ & $\cdots$ & $\ldots$ & $\cdots-$ & $\ldots$ & $-1-$ & 1 \\
\hline Aste & $-\quad 11$ & -1111 & $-\cdots$ & $--1-$ & $-\cdots$ & $-\cdots$ & $-\quad-$ & $\cdots$ & $\cdots$ & $-\cdots$ & $-\cdots$ & $\cdots-$ & \\
\hline & $\ldots$ & $1--1$ & $\ldots$ & - - - & $\ldots$ & $-\cdots$ & - - - & $\cdots$ & $-1-$ & $-\cdots$ & - - - & 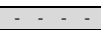 & \\
\hline & $-\ldots$ & $-\ldots$ & $\cdots-$ & $-\cdots$ & $-\ldots-1$ & $\begin{array}{llll}-1 & 1 & 1 \\
\end{array}$ & $-\ldots 1$ & $1-1$ & $1-1$ & $\begin{array}{llll}-1 & 1 & 1\end{array}$ & $\begin{array}{llll}-111 & 1\end{array}$ & $\begin{array}{lllll}1 & 1 & 1 & 1 \\
\end{array}$ & 20 \\
\hline SUM & $\begin{array}{llll}6 & 2 & 5 & 2\end{array}$ & 1777 & 10755 & 8762 & $\begin{array}{llll}8 & 6 & 4 & 1\end{array}$ & $\begin{array}{|lll|}11 & 13 & 5 \\
9 & \end{array}$ & 8762 & 9745 & $\begin{array}{llll}9 & 6 & 2 & 1\end{array}$ & $\begin{array}{llll}7 & 6 & 3 & 1\end{array}$ & $\begin{array}{llll}118 & 5 & 3\end{array}$ & $\begin{array}{llll}5 & 6 & 1 & 1\end{array}$ & 5.56 \\
\hline & & & & & & noflagellates & & & & & & & \\
\hline Prot & -- & $-1--$ & $\cdots$ & $-\cdots-$ & 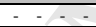 & $-1--$ & $1 \ldots$ & $-1-$ & $--1-$ & $-1-$ & $-\ldots$ & $-\cdots$ & \\
\hline & $\cdots$ & $-1--$ & $-\cdots$ & $-\cdots$ & $-\cdots$ & $-1--$ & $1--$ & -1 & $--1-$ & $-1-$ & $-\quad-$ & $-\cdots$ & \\
\hline & 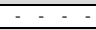 & $-\cdots$ & $\cdots$ & $\cdots$ & $\begin{array}{llll}1 & 1- & - \\
\end{array}$ & $-1-$ & $\begin{array}{llll}1 & 1 & 1 & - \\
\end{array}$ & $\begin{array}{lll}-1 & 1 & 1 \\
\end{array}$ & $\begin{array}{llll}1 & 1 & 1 & - \\
\end{array}$ & $1--$ & $1 \cdots$ & $\cdots$ & 14 \\
\hline & $\ldots$ & $\ldots$ & $\ldots$ & $-1-$ & $\begin{array}{llll} & 1 & - \\
\end{array}$ & $\begin{array}{|lll|}1 & 1 & - \\
\end{array}$ & $-1-$ & -11 & $-111-$ & $\cdots-$ & $\ldots$ & $\ldots$ & 9 \\
\hline & $-\quad-\quad-$ & $1---$ & ---- & ---- & $-\ldots$ & - - - & $1--$ & 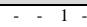 & 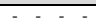 & $-\cdots-$ & 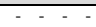 & $-\cdots-$ & 3 \\
\hline & $\cdots$ & $\cdots$ & $\cdots$ & $1 \cdots$ & $\cdots$ & $1 \ldots$ & $\begin{array}{llll}1 & 1 & 1 \\
\end{array}$ & $-1 \quad 1 \quad 1 \quad 1$ & $\begin{array}{llll} & 1 & 1 & - \\
\end{array}$ & $\cdots$ & $\cdots$ & $\cdots$ & 11 \\
\hline & $\ldots$ & $\ldots$ & $\cdots$ & $-\cdots$ & $\cdots$ & 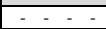 & $1 \ldots$ & -11 & $11-$ & $-\cdots$ & $\ldots$ & $\cdots$ & 5 \\
\hline & $-\ldots$ & --- & $1-\ldots$ & $-\cdots$ & $-\cdots$ & $-\quad--$ & $11--$ & $\cdots$ & $1--$ & --- & $-\ldots$ & $-\cdots$ & 4 \\
\hline & $\cdots$ & $\cdots$ & $\cdots$ & $-\ldots$ & 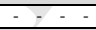 & $\cdots$ & $\begin{array}{llll}1 & 1 & 1 & - \\
\end{array}$ & $\cdots$ & $-111-$ & $\cdots$ & $\cdots$ & $\cdots$ & \\
\hline & $1--$ & $-\cdots$ & $\cdots$ & $\ldots$ & $\because \cdots$ & $\cdots$ & $\cdots$ & $1 \ldots$ & $1 \ldots$ & $\cdots$ & $\ldots$ & $\cdots$ & 3 \\
\hline & $-\ldots$ & $-\ldots$ & $\cdots$ & $-\cdots$ & $\ldots-$ & $-\cdots$ & $-\cdots$ & $\cdots$ & $1--$ & $-\cdots$ & $-\cdots$ & $-\cdots$ & \\
\hline & $\ldots$ & $-\ldots$ & $\cdots$ & $\cdots$ & $11-$ & $-\cdots$ & $1 \ldots$ & $\cdots$ & $\cdots$ & $\cdots$ & $\ldots$ & $\cdots$ & 3 \\
\hline & $-\quad--$ & $-\quad-\quad-$ & --- & ---1 & --- & $-\quad-\quad-$ & $1--$ & $-11-$ & $--1-$ & $-\cdots$ & $=--$ & $1--$ & \\
\hline & $\begin{array}{llll}1 & 0 & 0 & 0 \\
\end{array}$ & $\begin{array}{llll}1 & 2 & 0 & 0 \\
\end{array}$ & $\begin{array}{llll}1 & 0 & 0 & 0 \\
\end{array}$ & $\begin{array}{llll}1 & 1 & 0 & 1 \\
\end{array}$ & $\begin{array}{llll}3 & 3 & 0 & 0 \\
\end{array}$ & $\begin{array}{llll}2 & 4 & 0 & 0 \\
\end{array}$ & 105330 & 13383 & $\begin{array}{llll}6 & 5 & 7 & 0 \\
\end{array}$ & $\begin{array}{llll}1 & 2 & 0 & 0 \\
\end{array}$ & $\begin{array}{llll}1 & 0 & 0 & 0 \\
\end{array}$ & $\begin{array}{llll}1 & 0 & 0 & 0 \\
\end{array}$ & .58 \\
\hline & & & & & & & & & & & & & \\
\hline & $1 \cdots$ & $1-\cdots$ & -- & $11--$ & $\begin{array}{llll}1 & 1 & - \\
\end{array}$ & --1 & $-\cdots$ & $\cdots$ & $\cdots$ & $\cdots-$ & $\begin{array}{llll} & 1 & - \\
\end{array}$ & $\cdots-$ & 8 \\
\hline & $-\quad-\quad-$ & $-\quad-\quad-$ & $-\quad-\quad-$ & $-\quad-\quad-$ & $--1-$ & $-\quad-\quad-$ & $-\quad-\quad-$ & $\cdots$ & $--\quad-$ & $-\quad-\quad-$ & $-\quad-\quad-$ & $-\quad-\quad-$ & 1 \\
\hline & ---- & $-\quad-\quad-$ & --- & 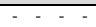 & 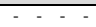 & $1-1$ & $\cdots$ & $\cdots$ & $\cdots$ & $\cdots-$ & $-\ldots$ & $\cdots$ & $\sqrt{2}$ \\
\hline & $-\ldots$ & $-1-$ & $1 \cdots$ & $\cdots$ & $\cdots$ & - - - - & $-\cdots-$ & $\cdots$ & $\cdots$ & $-\cdots$ & $-\cdots-$ & $-1-$ & \\
\hline Pedi & $-\quad-\quad-$ & $-\quad-\quad-$ & $--\quad-$ & --1 & $-\quad-\quad-$ & $-\quad-\quad-\quad-$ & $-\quad-\quad-$ & $\ldots$ & $-\quad-\quad-$ & $-\quad-\quad-$ & $-\quad-\quad-$ & - & 1 \\
\hline Ciliates & 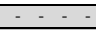 & -11 & $\cdots$ & $\cdots$ & $\cdots$ & $\because--1$ & $\cdots$ & $\cdots$ & $--1=$ & $-1-1$ & $\cdots$ & $\cdots$ & \\
\hline & $\begin{array}{lllll}1 & 0 & 0 & 0\end{array}$ & $\begin{array}{llll}1 & 2 & 1 & 0\end{array}$ & $\begin{array}{lllll}1 & 0 & 0 & 0\end{array}$ & $\begin{array}{lllll} & 1 & 1 & 1 & 0\end{array}$ & $\begin{array}{lllll} & 1 & 1 & 1 & 0\end{array}$ & $\begin{array}{llll}1 & 0 & 0 & 2\end{array}$ & $\begin{array}{lllll}0 & 0 & 0 & 0\end{array}$ & $\begin{array}{llll}0 & 0 & 0 & 0\end{array}$ & $\begin{array}{lllll}0 & 0 & 1 & 0\end{array}$ & $\begin{array}{llll}0 & 1 & 0 & 1\end{array}$ & $\begin{array}{llll}1 & 1 & 0 & 0\end{array}$ & $\begin{array}{llll}0 & 1 & 0 & 0\end{array}$ & 44 \\
\hline TOTAL SUM & $\begin{array}{llll} & 82 & 5 & 2\end{array}$ & $\begin{array}{llll}3 & 1187\end{array}$ & 12755 & 10973 & 121051 & $14175 \quad 11$ & 181292 & 1010128 & 1511101 & $\begin{array}{lllll}8 & 9 & 3 & 2\end{array}$ & 13953 & $\begin{array}{lllll}6 & 7 & 1 & 1\end{array}$ & 7.58 \\
\hline
\end{tabular}




\section{ACCEPTED MANUSCRIPT}

Table 1. Presence and absence of the diatoms, dinoflagellates and other algal group taxa observed by optic microscopy from January to December 2015 in the sub-surface layer at sites 1, 3, 5 and 7. $X X X$ represent unidentified taxonomic units.

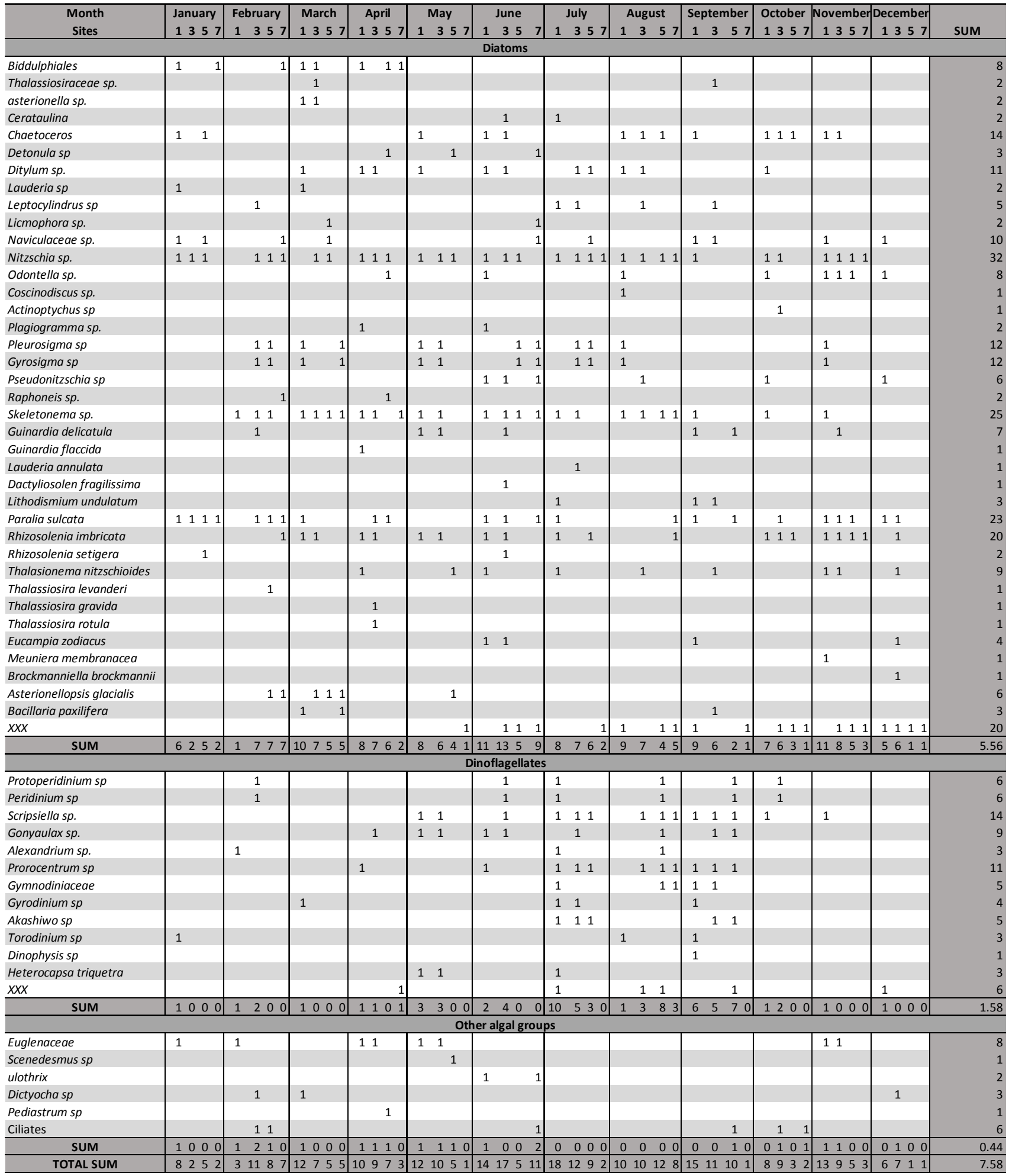


Table 2. Spearman correlation coefficients obtained between the exopolysaccharides (TEP, S-EPS and BEPS) and the biological, physical and chemical parameters ( $n=96$ in the sub-surface layer, and $n=48$ close to the WSI), the pico/nano abundances (Synechococcus, Pico-eukaryotes and Cryptophyceae; $n=72$ in the sub-surface layer and $n=48$ close to the WSI) and the diatom and dinoflagellate abundances ( $n=48$ in the sub-surface layer only). The coefficients were considered significant when the p-value was $<0.05$, if not, it was noted "NS").

\begin{tabular}{|c|c|c|c|c|c|c|}
\hline \multirow[b]{2}{*}{ Parameters } & \multicolumn{3}{|c|}{ Sub-surface layer } & \multicolumn{3}{|c|}{ Water sediment interface } \\
\hline & TEP & S-EPS & B-EPS & TEP & S-EPS & B-EPS \\
\hline Temperature & -0.69 & 0.46 & 0.24 & -0.35 & 0.35 & NS \\
\hline Salinity & -0.22 & NS & $\mathrm{NS}$ & -0.46 & NS & NS \\
\hline Irradiance & $-\mathbf{0 . 6 0}$ & 0.52 & 0.62 & - & - & - \\
\hline Turbidity & 0.81 & -0.46 & -0.35 & 0.67 & NS & NS \\
\hline SPM & 0.50 & -0.51 & -0.56 & 0.77 & -0.58 & -0.56 \\
\hline DIN & 0.36 & -0.20 & NS & 0.54 & NS & NS \\
\hline $\mathbf{P}$ & NS & NS & -0.21 & 0.61 & -0.32 & -0.35 \\
\hline Si & 0.42 & -0.38 & -0.19 & 0.54 & NS & NS \\
\hline $\mathbf{F}_{\mathbf{V}} / \mathbf{F}_{\mathbf{M}}$ & NS & NS & NS & -0.53 & NS & NS \\
\hline Large Chla & -0.36 & 0.29 & 0.23 & 0.33 & NS & NS \\
\hline Small Chla & $-\mathbf{0 . 5 0}$ & 0.29 & 0.25 & NS & NS & NS \\
\hline Total Chla & -0.52 & 0.34 & 0.28 & NS & NS & NS \\
\hline TEP & - & -0.57 & -0.40 & - & -0.60 & -0.54 \\
\hline S-EPS & -0.57 & - & 0.81 & -0.60 & - & 0.93 \\
\hline B-EPS & -0.40 & 0.81 & - & -0.54 & 0.93 & - \\
\hline Synechococcus Ab. & NS & NS & NS & NS & NS & NS \\
\hline Pico-eukaryote Ab. & -0.42 & NS & NS & NS & NS & NS \\
\hline Cryptophyceae Ab. & NS & 0.23 & NS & -0.43 & 0.33 & NS \\
\hline Diatom Ab. & $-\mathbf{0 . 3 1}$ & 0.28 & 0.28 & - & - & - \\
\hline Dinoflagellate Ab. & -0.36 & 0.28 & NS & - & - & - \\
\hline
\end{tabular}




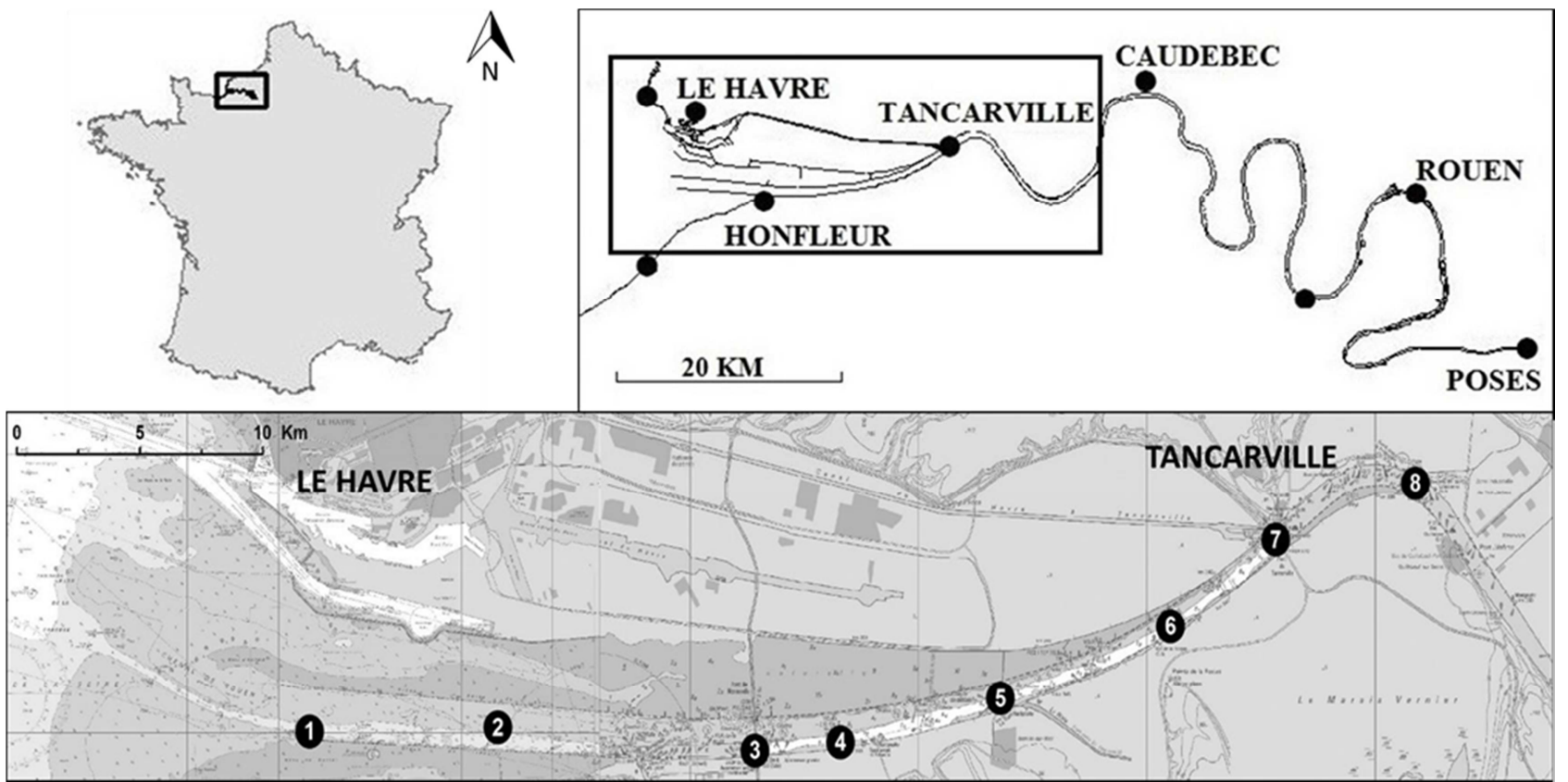

Figure 1. Map of the Seine estuary (Longitude: 0.2327, latitude: 49.4326 (WGS84) - Normandy, France) showing the study area. Poses is the upper limit of tidal propagation. The sampling transect from site 1 to site 8 followed the salinity gradient from the euhaline zone (Site 1- L: 0.1116, 1: 49.4335) to the oligohaline zone (site 8 - L: $0.5149,1$ : 49.4841). The sites were sampled monthly throughout 2015. 


\section{ACCEPTED MANUSCRIPT}
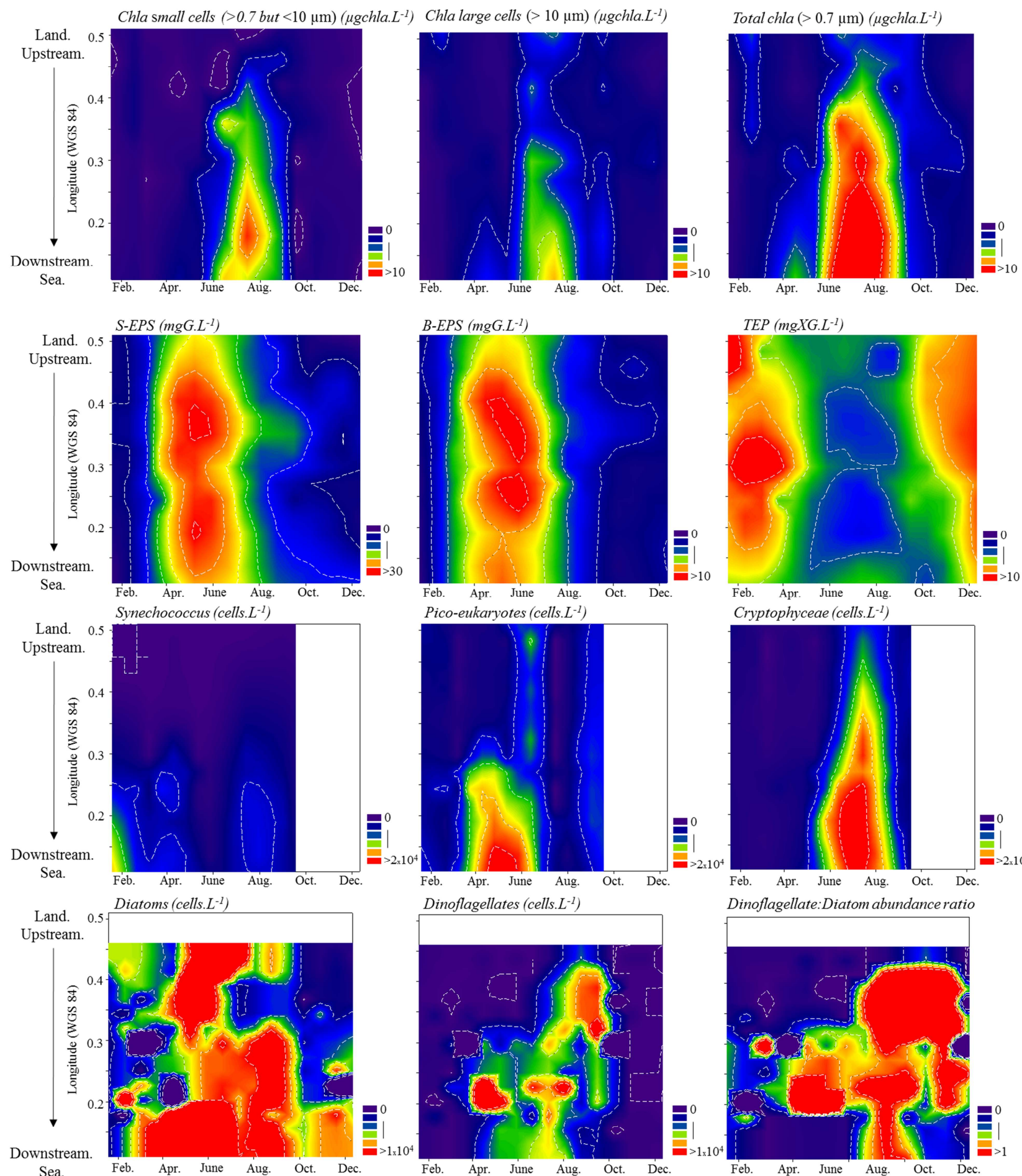

Figure 2. Variations in the parameters in the sub-surface layer $(1 \mathrm{~m}$ under the surface) of the Seine estuary from January to December, 2015. With total, small cell and large cell chla concentrations $\left(\mu \mathrm{gchl} a . \mathrm{L}^{-1}\right)$; S-EPS, B-EPS (mgG.L $\mathrm{L}^{-1}$ ) and TEP concentrations (mgXGeq.. $\left.{ }^{-1}\right)$; Synechococcus, Pico-eukaryotes, Cryptophyceae, diatom and dinoflagellate abundance (cells. $\mathrm{L}^{-1}$ ). The dinoflagellate:diatom abundance ratio is also given. Values were previously smoothed using the Loess non-parametric regression method. 


\section{ACCEPTED MANUSCRIPT}
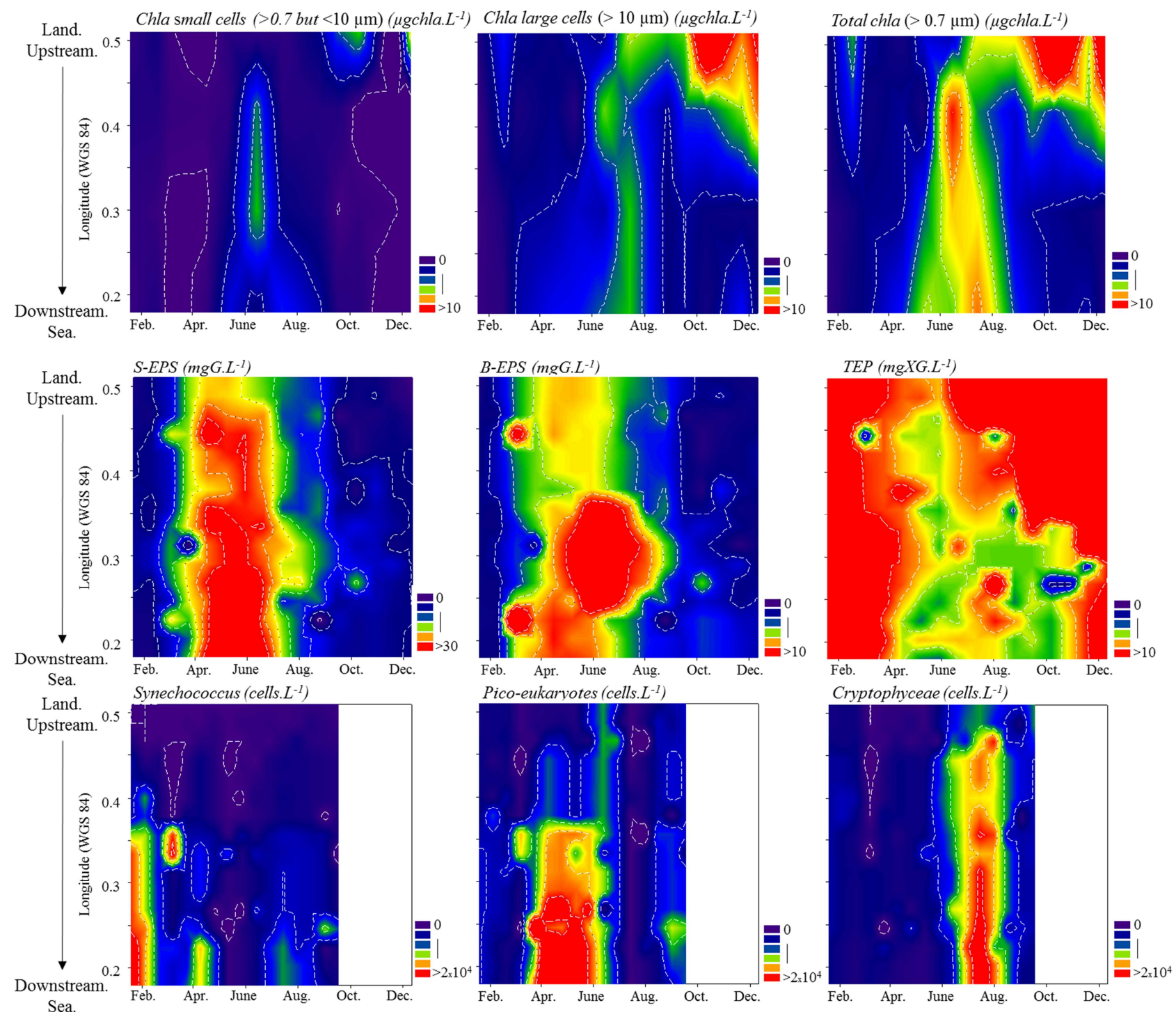

Figure 3. Variations in the parameters close to the water/sediment interface $(1 \mathrm{~m}$ above the sediment) in the Seine estuary from January to December, 2015. With total, small cell and large cell chla concentrations $\left(\mu \mathrm{gchl} a . \mathrm{L}^{-1}\right)$; S-EPS, B-EPS (mgG.L ${ }^{-1}$ ) and TEP concentrations (mgXGeq.L ${ }^{-1}$ ); and Synechococcus, Pico-eukaryotes, and Cryptophyceae abundances (cells. $\mathrm{L}^{-1}$ ). Values were previously smoothed using the Loess non-parametric regression method. 

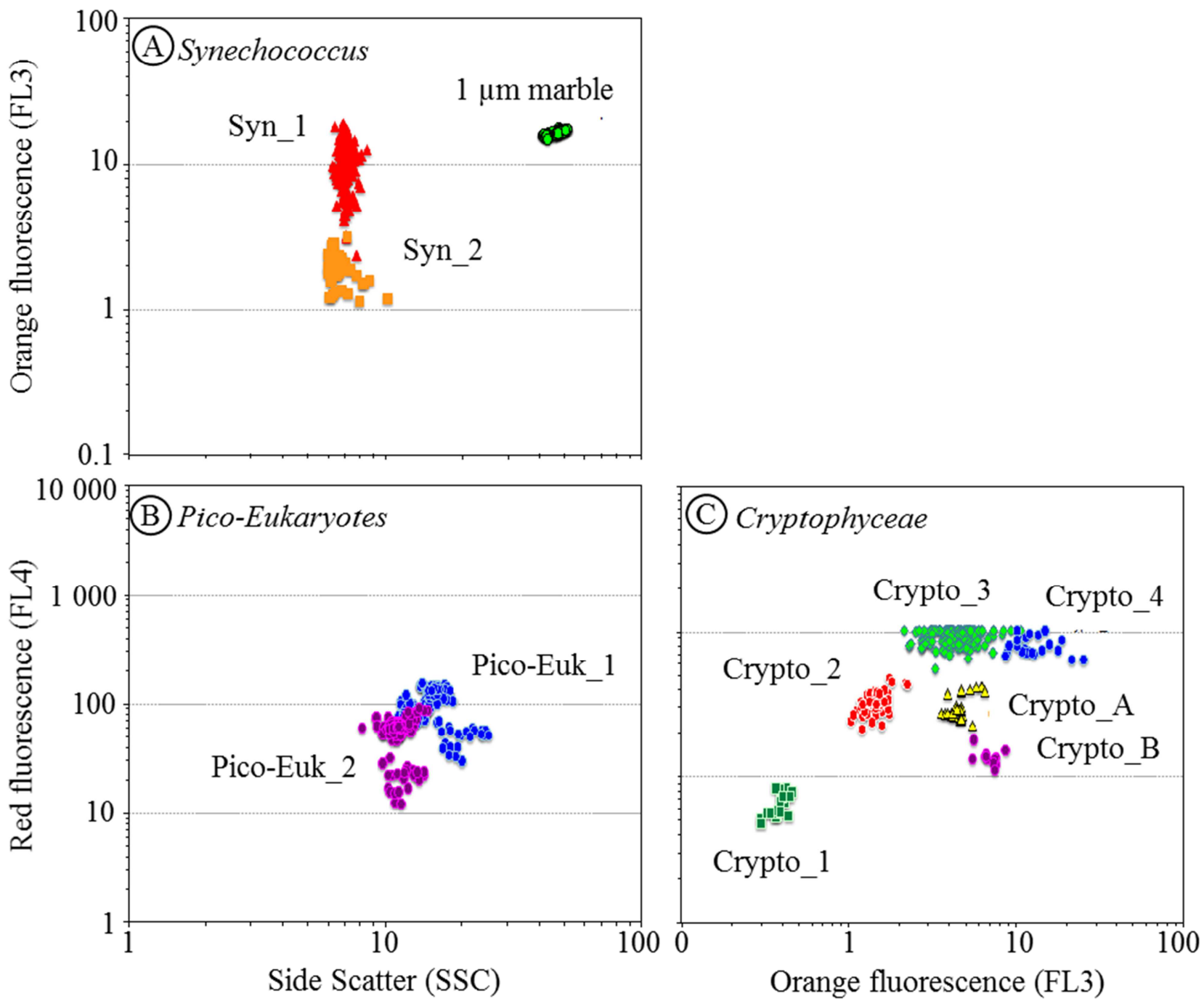

Figure 4. Cytometric signatures of the different populations observed in 2015 along the Seine estuary. A $1 \mu \mathrm{m}$ selffluorescent latex marble was added to each sample as a size and fluorescence reference. The graphs show the FL3 median (phycoerythrin), FL4 median (chlorophyll) and SSC median (size). With the two Synechococcus populations (A), the two pico-eukaryote populations that were not significantly differentiated $(\mathrm{B})$ and the six Cryptophyceae populations (C). 


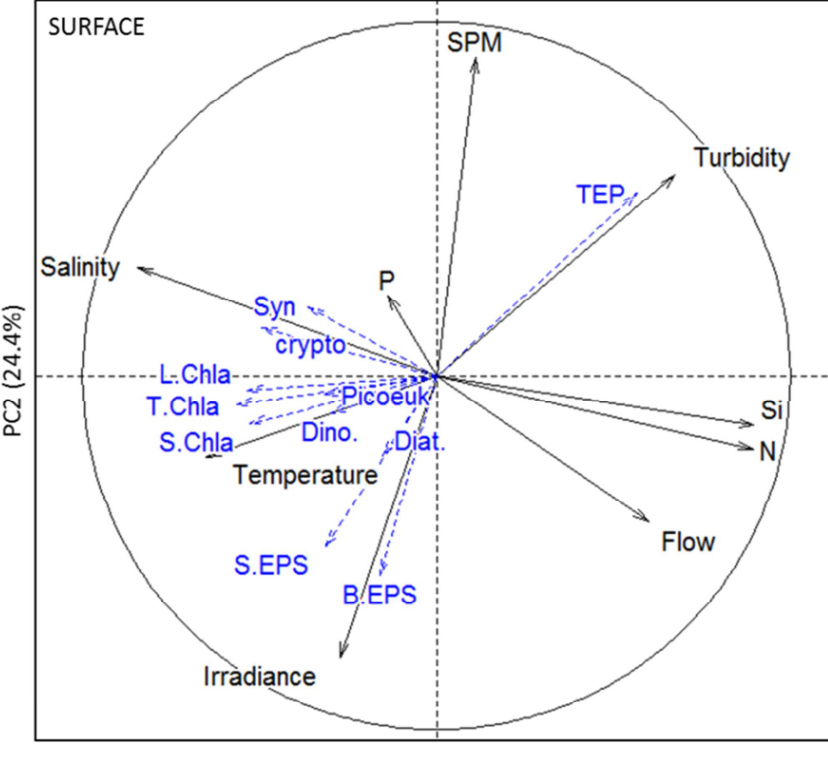

PC1 (40.7\%)

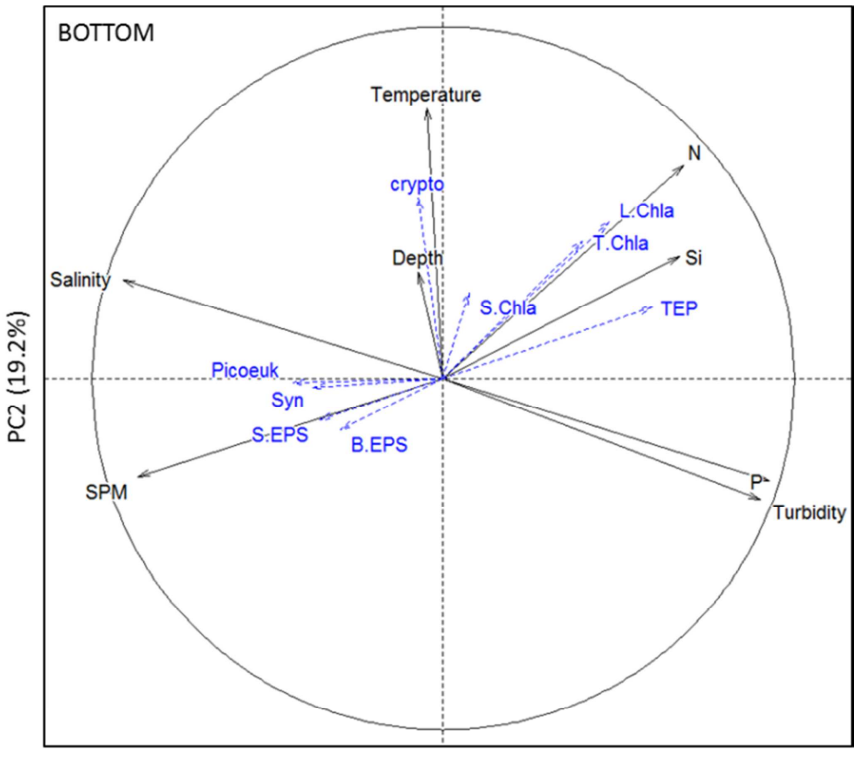

PC1 (52.3\%)

Figure 5. Representation of Principal Component Analysis (PCA) using the abiotic parameters as qualitative variables (Irradiance $\left(\mathrm{J} \mathrm{cm}^{2}\right)$, flow $\left(\mathrm{m}^{3} \mathrm{~s}^{-1}\right)$, temperature $\left({ }^{\circ} \mathrm{C}\right)$, salinity $(\mathrm{PSU}), \mathrm{SPM}\left(\mathrm{g} \mathrm{L}^{-1}\right)$ and nutrients $\left(\mu \mathrm{mol} \mathrm{L} \mathrm{L}^{-1}\right)$ : DIN, $\mathrm{P}$ and $\mathrm{Si}$ ) and the biological parameters as quantitative variables (total chl $a$ (T.Chla) and chl $a$ of small and large cells (S.Chla and L.Chla) in $\mu \mathrm{g} \mathrm{L}^{-1}$, Transparent exopolymeric particles (TEP) in $\mathrm{mgXGeq} \mathrm{L}^{-1}$, Soluble and Bound exopolymeric substances (S.EPS and B.EPS) concentrations in $\mathrm{mgEPS} \mathrm{L}^{-1}$ and the abundance of phytoplankton community (Synechococcus (Syn), Cryptophyceae (crypto), Pico-eukaryotes (Picoeuk), diatoms (Diat.) and dinoflagellates (Dino.) in cells $\left.\mathrm{L}^{-1}\right)$ ). The sub-surface water was represent in the left panel and the water sediment interface in the right panel. 


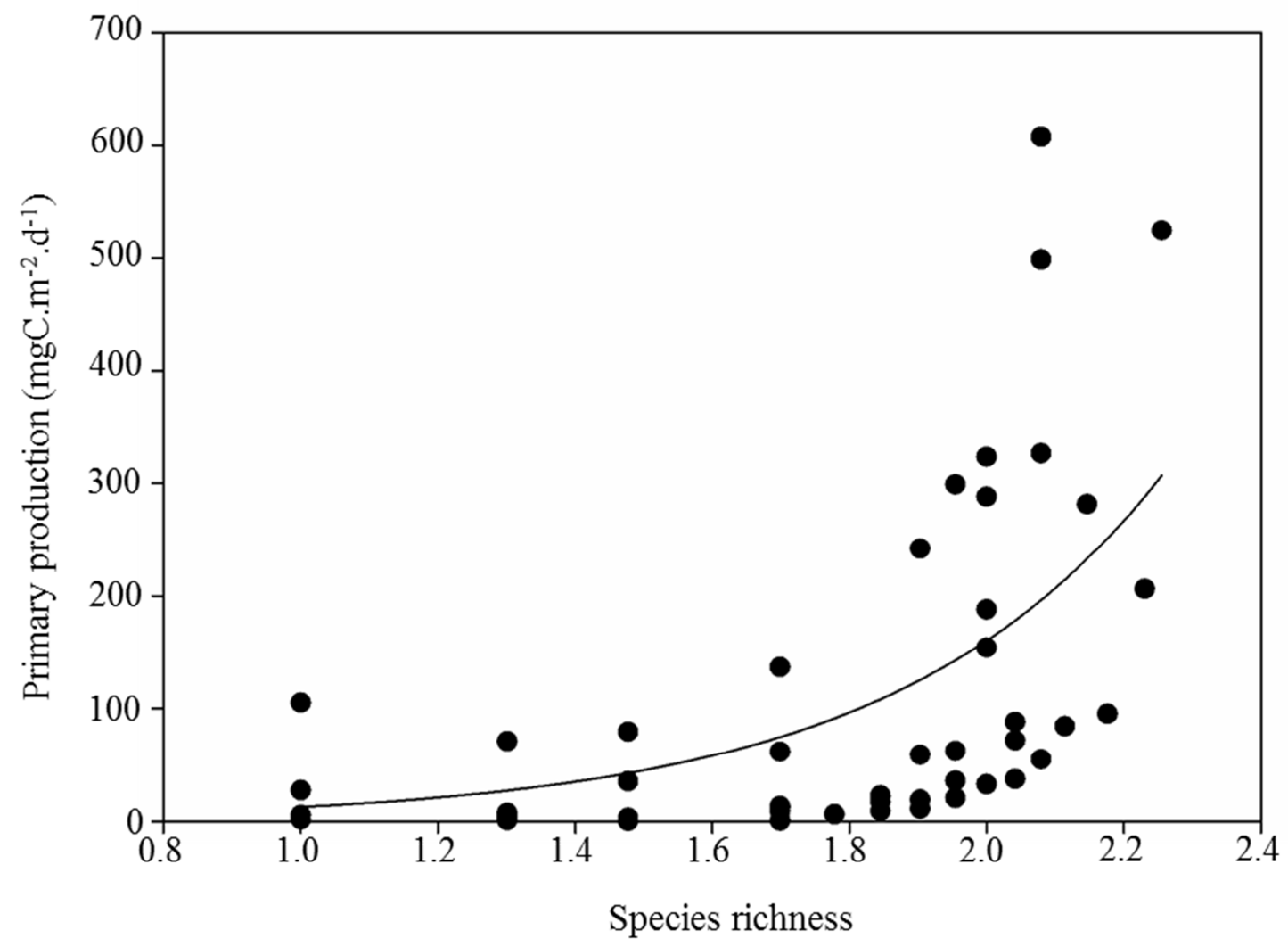

Figure 6. Primary production as a function of the species richness of the Seine estuary. All the spatial (sites 1, 3, 5 \& 7) and temporal (from January to December) data were used in this plot. Species richness was calculated as a function of the microscopic observations made in this study (table 1) and expressed in $\log _{10}+1$. The primary production data $\left(\mathrm{gC} . \mathrm{m}^{-2} \cdot \mathrm{d}^{-1}\right)$ are detailed in Morelle et al. (submitted). The dynamic fit was performed on SigmaPlot 12.5 after 200 iterations of fits and the final equation was $\mathrm{PP}=\mathrm{e}^{2.5 \times \mathrm{SR}}\left(\mathrm{p}<0.001 ; \mathrm{R}^{2}=0.35\right)$. 